1 2 3

14

5 Authors:

6 Ramón Mas ${ }^{1,3}, M^{a}$ Eugenia Arribas ${ }^{2,} \dagger$, Laura González-Acebrón ${ }^{1}$, I. Emma Quijada ${ }^{4}$, Sonia Campos-

7 Soto ${ }^{1,3}$, Pablo Suarez-Gonzalez ${ }^{5}$, Sara Sacristán-Horcajada ${ }^{1}$, José Arribas ${ }^{2,3}$, M. Isabel Benito ${ }^{1,3}$, Carlos

8 Pérez-Garrido ${ }^{2}$, Ángela Alonso*6.

9

10

11 1. Departamento de Geodinámica, Estratigrafía y Paleontología, Universidad Complutense de Madrid, C/ 12

\section{COASTAL WETLANDS AS MARKERS OF TRANSGRESSION IN PROXIMAL EXTENSIONAL SYSTEMS (BERRISASIAN, W CAMEROS BASIN, SPAIN)}

Addresses: José Antonio Nováis 12, 28040 Madrid, Spain.

2. Departamento de Mineralogía y Petrología Universidad Complutense de Madrid, C/ José Antonio Nováis 12, 28040 Madrid, Spain.

3. Instituto de Geociencias IGEO (CSIC, UCM), C/ Severo Ochoa 7, Ciudad Universitaria, 28040 Madrid, Spain.

4. Departamento de Geología, Universidad de Oviedo, C/ Jesús Arias de Velasco s/n, 33005 Oviedo, Spain

5. Área de Geología, Universidad Rey Juan Carlos, C/ Tulipán s/n, Móstoles, Spain.

${ }^{6}$ Retired. Department of Navigation and Earth Sciences. University of A Coruña, A Coruña, Spain

† Corresponding Author: Tel.: +34913944918. Fax: +34915442535.

Email: earribas@geo.ucm.es 
The early stages of intraplate extensional systems commonly are recorded by deposition of continental sediments. In this context, given appropriate tectonics and eustasy, transgressions can be well recorded in the areas of the basins located close to the sea, but they may be difficult to recognize in the innermost landwards areas of the system. This situation occurs in the innermost Upper Jurassic-Early Cretaceous Cameros Basin, part of the Iberian Extensional System (N. Spain), where a Berriasian transgression is recorded. The Berriasian succession in this area consists of siliciclastic deposits (sandstone and mudstone) of the Salcedal Formation and of carbonate and mixed carbonate-fine siliciclastic deposits (limestone and marl) of the San Marcos Formation. The sedimentological analysis of this depositional succession indicates that a Berriasian carbonate coastal wetland system occupied that sector of the Cameros Basin during deposition of the San Marcos Formation. This carbonate coastal wetland system consisted of shallow and quiet water bodies including some with marine influence others with no to very little marine influence, and palustrine areas. A semiarid climate characterized by the seasonal alternation of short wet and long dry periods caused water bodies of the system to undergo episodic desiccation and subaerial exposure. Moreover, this complex mosaic of sub-environments was connected laterally with a distal zone of a distributive fluvial system that was rimmed by siliciclastic tidal flats during phases of greater marine influence.

The paleogeographic arrangement of this coastal wetland depositional system indicates that the marine influence came from the Basque-Cantabrian Basin to the north. During the period of Berriasian maximum marine influence, accommodation linked to the eustatic rise added to accommodation generated by tectonic subsidence from the extensional reactivation of late Variscan strike-slip faults. All these factors favored marine incursion into the west Cameros Basin from the Basque-Cantabrian Basin to the north. The example of the Berriasian transgression recorded in the W Cameros Basin by establishment of coastal wetland systems matches the interpretations of previous studies in neighboring areas. In those areas, complex coastal systems record transgressions in the innermost parts of the intraplate extensional basins of the Iberian Plate. This observation suggests that this paleogeographic and sedimentological arrangement may be common in the innermost parts of intraplate extensional basins during transgressive episodes throughout the geological record. 
KEYWORDS: Coastal wetland, carbonates, Earliest Cretaceous transgression, innermost Iberian Basins,

West Cameros sub-Basin, N Spain.

\section{INTRODUCTION}

Depositional successions developed during the early stages of intraplate extension commonly are dominated by siliciclastic deposits, which pass gradually into carbonate deposits (Gawthorpe and Leeder 2000). These carbonates can be purely continental or show marine influence, depending on their tectonic and paleogeographic setting, as well as on the eustatic context during deposition (Gawthorpe and Leeder 2000). In intra-plate rift systems formed during transgressive episodes marine facies are likely to be deposited in the areas closer to the sea, but the marine influence on the innermost, landward areas of the system can be scarce or hard to detect, and therefore they may have been often overlooked in the geological record. This non-recognition of the marine influence has been frequent in the TithonianBerriasian record of the innermost areas of extensional basins of NE Iberian Peninsula.

During the Late Jurassic and Early Cretaceous, two main extensional systems developed in the NE of Iberia: the Basque-Cantabrian Basins Extensional System (BCB) to the N, and the Iberian Basins Extensional System (IB), which crosses the eastern part of the Iberian plate from NW to SE (Fig. 1). A Berriasian transgressive episode has been identified by marine deposits at the distal outermost areas of both IB (e.g. Salas et al. 2001) and BCB (e.g., Pujalte et al. 2004), but the inner landward location of the Cameros Basin within the IB (its innermost NW area, Fig. 1), hindered the deposition of thick marine deposits. Nevertheless, in the eastern sector of the Cameros Basin (Fig, 2A), coastal siliciclastic, carbonate and evaporite deposits, some with tidal influence (Quijada et al. 2013a, 2016a, b), indicate that the Berriasian transgression reached the innermost part of the Iberian Plate and its extensional areas. This study is focused on the western sector of the Cameros Basin (Fig. 2), where Berriasian carbonate 

of marine influence in their sedimentation. Therefore, results will not only help to correlate the W Cameros deposits with coeval units and to reconstruct the paleogeography of NE Iberia during the Berriasian, but they will also contribute to the knowledge of how transgressions can be recorded in the innermost parts of intraplate extensional basins.

\section{GEOLOGICAL SETTING}

The studied deposits are part of the sedimentary infill of the Cameros Basin, which is located in the northern sector of the Iberian Range (Fig. 2A), and is the northwesternmost basin of the Mesozoic IB (Fig. 1A; Mas et al. 1993; Guimerà et al. 1995; Salas et al. 2001; Mas et al. 2002, 2011). The evolution of Cameros Basin can be divided into four megasequences bounded by main unconformities: the Permian Triassic Megasequence 1, the Jurassic Megasequence 2, the Latest Jurassic - Early Cretaceous Megasequence 3, and the Late Cretaceous Megasequence 4 (Salas et al. 2001; Mas et al. 2002, 2003, 2011). Two megasequences (1 and 3) correspond to extensional syn-rift phases, and two (2 and 4) correspond to post-extensional, predominantly post-rift thermal, phases (Fig. 1B). In the Cameros Basin, the sedimentary record of Megasequence 3 (Early Tithonian to Early Albian) lies unconformable on top of Middle to Upper Jurassic marine platform deposits of Megasequence 2 (Fig. 2A and B; Fig. 3 A). The sedimentary infill during Megasequence 3 is composed of alluvial, fluvial, lacustrine and coastal sediments (Mas et al. 1993, 2002 and 2011; Sacristán-Horcajada et al. 2012a,b; Quijada et al. 2013a,b, 2016a,b; Suarez-Gonzalez et al. 2013, 2014, 2015, 2016a,b), and is divided into eight depositional sequences (DS) bounded by unconformities (Fig. 3A). During the Alpine Orogeny, the Cameros Basin was inverted, and acquired its current pop-up compressive structure (Fig. 2B). It includes a north-verging, neoformed, main compressional structure that thrusts the Cameros Basin structural unit onto the Cenozoic Ebro Basin, and a south-verging secondary structure that thrusts the Cameros Basin structural unit onto the Duero-Almazán Basin (Fig. 2A and B) (Guimerà et al. 1995; Casas-Sainz et al. 2000).

The Cameros Basin is divided into two sectors (Mas et al., 1993; Fig. 2A): a western sector (W Cameros Basin) and an eastern sector (E Cameros Basin). The E Cameros Basin had the higher subsidence rates, comprising up to $6500 \mathrm{~m}$ of sediments (Mas et al. 2002, 2003, 2011; Omodeo-Salé et al. 2014), whereas the W Cameros Basin had much lower subsidence rates, accumulating less than a third of 
115 the thicknesses of the eastern sector (Fig. 2B). The current compressive structure of the W Cameros Basin 116 consists of a set of thrusts and folds with a NW-SE orientation (Fig. 2C), limited and cut by strike-slip 117 faults with a NNE-SSW orientation (Beuther 1966; Salomon 1982; Platt 1990; Clemente and Pérez118 Arlucea 1993; Guimerà et al. 1995; Martín-Closas and Alonso 1998; Sacristán-Horcajada et al. 2012c, 119 2015). These structures resulted from inversion of an extensional feature during the Alpine Orogeny, 120 structures that consisted of half-grabens limited by NW-SE normal faults and linked by NNE-SSW 121 transfer zones (Platt 1990; Guimerà et al. 1995; Martín-Closas and Alonso 1998; Sacristán-Horcajada et al. 2012c, 2015). Three different sectors have been distinguished in the W Cameros Basin (Fig. 2C): the 123 northern sector, with southwest-dipping thrusts, which include the area south of the La Demanda Massif; the central sector, which includes the area around the north-dipping Moncalvillo Thrust; and the southern sector, which includes the area around the northeast-dipping San Leonardo Thrust and the South Cameros Thrust.

The focus of this study are deposits representing the third depositional sequence (DS 3) of the Tithonian-Berriasian mega-sequence in the $\mathrm{W}$ Cameros Basin (Fig. 3A), which corresponds to the siliciclastic Sandstone and mudstone of the Río del Salcedal Formation and the carbonate Limestone and marl of the Río de San Marcos Formation (hereafter Salcedal Formation and San Marcos Formation, Fig. 3A and B). The relatively poor biostratigraphic data available are based on charophyte and ostracods associations. The charophyte associations indicate that, although the San Marcos Formation contains characteristic flora attributable to the Tithonian - Early Berriasian interval, the Tithonian - Berriasian mega-sequence in its upper part (San Marcos Formation) would reach a Middle Berriasian age (Schudack 1987; Platt 1989b; Martín-Closas and Alonso-Millán 1998). According to Schudack and Schudack (2009, 2012) the ostracod associations indicate that the depositional sequence 2 (DS 2), that is overlain by the depositional sequence under study (DS 3), contains a rich freshwater association consistent with a Berriasian age. Clemente (2010) attributed an Early Berriasian age to the ostracod assemblage in a succession constituted by the Jaramillo, Campolara, Salcedal, and San Marcos Formations (DS 2 and DS 3), which Clemente (2010) considered as a single formation named Rupelo Formation, following the stratigraphic units defined by Platt (1989b). According to all the previous biostratigraphic data, the deposits of this study are considered Early to Middle Berriasian in age. 


\section{METHODS}

General large-scale geological mapping was supplemented by detailed geological mapping of different outcrops at 1:10,000 scale. Twenty-nine stratigraphic sections were studied and sampled in detail (Fig. 2C). A specific sedimentary facies analysis of the third depositional sequence (DS 3) was carried out using enlarged aerial orthophoto scale and outcrop scale field observations and study of more than 100 thin sections. The petrographic analysis included a transmitted-light microscopic examination of polished and uncovered thin sections. The thin sections were prepared using standard procedures including (1) impregnation with blue epoxy resin to highlight porosity and (2) selective staining and etching to identify feldspar (Friedman 1971; Norman 1974) and carbonate minerals (Lindholm and Finkelman 1972).

Regarding the terminology of depositional systems, the term "coastal wetland" is used here following geomorphological definitions of modern environments, as applied to ancient deposits by Suarez-Gonzalez et al. (2015). Thus, it refers to a depositional system located in the coastal zone, composed of areas which are partly inundated and partly emerged, due to a fluctuating water table that is at least partially controlled by sea level (Ramsar Convention 2002; Mendelssohn and Batzer 2006; Baldwin et al. 2009; Wolanski et al. 2009).

61

(1)

\section{RESULTS}

\subsection{Stratigraphic architecture of the third depositional sequence (DS3) in W Cameros Basin}

The syn-extensional sedimentary record of the W Cameros Basin (Fig. 3B) is divided into seven depositional sequences, which correspond to twelve lithostratigraphic units (Mas et al., 2004). The Tithonian-Berriasian sedimentary record of the $\mathrm{W}$ Cameros Basin consists of three depositional sequences (DS 1, DS 2 and DS 3), and includes six formations (Table 1 and Figure 4A-D). DS 3, the focus of this study, appears exclusively in the north sector of the W Cameros Basin (Figs. 4E, F, 5), and comprises two formations. The Salcedal Formation (lower part of DS 3), is 0 to $69 \mathrm{~m}$ thick, with a depocenter located in the SE part of the north sector at the Castrovido Section (Figs. 2C, 4E, 5), thinning towards the NW (Fig. 4E). The San Marcos Formation (upper part of DS 3) is 0 to $84 \mathrm{~m}$ thick and its depocenter is located in the central-northern part of the north sector at the Rupelo Section (Figs. 2C, 4F, 
175

176

177

178

179

180

181

182

183

184

185

186

187

188

189

190

191

192

193

194

195

196

197

198

199

200

201

202

203

204

5). A distinctive feature of the San Marcos Formation is that it contains abundant dinosaur tracks, which are particularly noteworthy at the top of the unit (Torcida Fernández-Baldor et al. 2015). DS 3 also occurs in a small isolated outcrop located in the north-westernmost part of the study area, in which the Arlanzón Section was logged (Fig. 2C). In this section, the Salcedal and San Marcos formations are respectively 34 and $43 \mathrm{~m}$ thick.

\subsection{Sedimentology of the third depositional sequence (DS 3): Facies Associations}

The strata include twelve sedimentary facies: five siliciclastic lithofacies sensu Miall (2010) and seven carbonate lithofacies (Table 2). The twelve different sedimentary facies correspond to 9 different types of architectural elements (Figs. 6, 7) sensu Miall (2010). In addition, these facies and architectural elements are grouped into 6 distinct facies associations with different environmental significance within the recognized depositional systems (Fig. 7).

\subsubsection{Facies Association 1 (FA-1)}

FA-1, best represented in the Castrovido section (Fig. 6), is made up of 4 different facies arranged into 5 types of architectural elements (Fig. 7). The most characteristic facies of FA-1 consists on tens of meters-wide lenses of trough cross-bedded sandstone (St). St facies is arranged into sandy bedforms (SB), which are sometimes organized as medium- to large-scale lateral-accretion forms (LA, Fig. 8A) in concave-up erosionally based channel bodies $(\mathrm{CH})$. Paleocurrent data of the cross-bedding are scarce but indicate a predominant $\mathrm{W}$ to SW orientation (Fig. 6). The sandy architectural elements are interbedded with floodplain fines (FF), composed mainly of several meters to tens of meters-thick extensive sheets of massive siliciclastic sandy mudstone, which displays root traces and pedogenetic carbonate concretions (Fm). The floodplain fines (FF) contain intercalations of thin sheets of horizontalbedded and cross-laminated fine sandstone (Sh, Fig. 8A) and paleosol carbonate layers (calcretes) with low lateral continuity and pedogenetic features, such as nodular structure $(\mathrm{P})$.

Interpretation. This association is interpreted as the result of sedimentation of sinuous, channelized bedload in meandering channels and vertical accretion of floodplain deposits in the distal portion of a fluvial system. The concave-up, erosionally based channeled bodies showing medium- to large-scale lateral-accretion forms (SB, CH and LA in Fig. 7), correspond to lateral accretion extensive point-bars on the inside of the channel meander bends (Bridge 2006; Miall 2010). The relatively thick 
205

206

207

208

209

210

211

212

213

214

215

216

217

218

219

220

221

222

223

224

225

226

227

228

229

230

231

232

233

234

extensive sheets of massive siliciclastic mudstone showing root traces and nodular and massive paleosol carbonate layers stand for vertically accreted floodplain fines in the overbank areas with episodic pedogenetic calcretes formed during drier phases (Bridge 2003 and 2006; Miall 2010; SacristánHorcajada et al. 2016). The thin sheets of horizontal-bedded and cross-laminated fine sandstone interbedded with the massive siliciclastic mudstone characterize crevasse splay deposits that directly spread on the floodplain from breaks in the channel bank (Bridge 2006; Miall 2010). The architecture of this facies association shows a net predominance of the suspended load units with respect to the bed load units. This architectural arrangement, together with the lateral accretion recognized in the channeled bodies, indicate a distal fluvial system with a single mobile channel (Friend 1983) that seems to indicate a facies-architecture of the distal zone of a single-thread meandering fluvial system (Davison et al. 2013). It probably corresponds to the distal zone of a relatively small distributive fluvial system (DFS, sensu Weissmann et al. 2010, Hartley et al. 2010), likely located northeast of the study area.

\subsubsection{Facies Association 2 (FA-2)}

FA-2, which occurs only in the uppermost part of the Castrovido section (Fig. 6), is composed of 3 facies and 2 architectural elements (Fig 7). It consists of heterolithic sandy to mixed flat architectural elements (SMF) composed of extensive sheets of rippled wavy- and flaser-bedded sandstone (SrF, Fig. 8B) with some associated channelized trough cross-bedded sandstone that occasionally displays very thin mud laminae between the sandstone foreset laminae (St). These SMF architectural elements are interbedded with extensive sheets of siliciclastic mudstone (Fm) that correspond to mud-flat architectural elements (MF).

Interpretation. This association corresponds to a mixed-flat to mud-flat environment in a siliciclastic tidal flat. The extensive non-channelled heterolithic sheets with wavy- and flaser-bedded sandstone $(\mathrm{SrF})$ interbedded with siliciclastic mudstone $(\mathrm{Fm})$ suggests deposition in broad, flat areas in which episodes of frequent alternating bedload transport and settling from suspension alternated with episodes of exclusive settling from suspension (Klein 1998). Specifically, SrF facies is interpreted as deposited in mid-high intertidal flats due to its similarities with present-day analogues (e.g., Nio and Yang 1991; Dalyrymple 1992, 2010), such as the classical tidal flats of the North Sea (Reineck and Wunderlich 1968; Reineck 1972), and other coastal tidal flats, such as the Baie du Mont Saint Michel (Tessier 1993), San Francisco Bay (Pestrong 1972), the Bay of Fundy (Klein 1985), North West Australia 
235 (Semeniuk 1981), and the Gulf of California (Thompson 1968). A nearly equal period for both suspension 236 and bed load sedimentation occurs in the mid-tidal flats (Klein 1998), generating a tidal rhythmite of 237 interbedded sand and mud (DeRaaf and Boersma 1971; Dalyrymple 2010) similar to that observed in the 238 SrF facies. The associated Fm facies is interpreted to have been deposited in areas in which settling of 239 fine-grained silts and clays predominated, such as present-day high tidal flats. These areas are submerged 240 for less than one third of a tidal cycle, during periods of high water level, when velocities are negligible 241 (Klein 1998). The cross-bedded channeled sandstone with occasional mud-draped foreset laminae (St) would correspond to channel deposits showing tidal bundles, which is also a diagnostic structure associated with sandy bedforms in tidal sedimentary environments (Allen and Homewood 1984; Dalyrymple 2010). These mud-draped cross strata are the result of alternating bedform migration during high flow velocities and mud deposition during high and low tide slackwater in subtidal areas and during

\subsubsection{Facies Association 3 (FA-3)}

FA-3 is present in the Rupelo and Arlanzón sections (Fig. 6), and comprises interbedded marls and laterally extensive, centimeter- to meter-thick, carbonate tabular beds (IMC, Figs. 7, 8C). Carbonate beds consist of well-bedded marly foraminiferal limestone and display parallel lamination (Lbf). Locally, disperse rizoliths, black pebbles and desiccation cracks occur on top of Lbf beds (Fig. 8D). The depositional textures are bioclastic mudstone, wackestone and packstone. The biotic association includes benthic foraminifera, such as miliolids and other minute indeterminate forms (Fig. 9A to E), ostracods (Fig. 9B), fish scales and teeth, and gastropods. After ostracods, miliolids (0.5 mm-thick, porcelanous tests) are the most abundant component in the Rupelo section, whereas in the northernmost area (i,e., the Arlanzón section) foraminifera correspond to minute indeterminate forms (trochospiral types, smaller than $0.1 \mathrm{~mm}$. Figs. 9D and 9E). Ostracods have both complete and disarticulated carapaces, their valves are smaller than $0.5 \mathrm{~mm}$, and have a finely prismatic microstructure sometimes with a "cup-in-cup" arrangement (Fig. 9B). Generally, the valves are smooth, but crenulated forms are locally observed. Other minor skeletal grains are charophytes. Micrite matrix is abundant, although it can appear clotted to peloidal and be dolomitized, and it can include mm-scale parallel laminations. Micritic micro-filaments are locally observed. Large (more than $10 \mathrm{~mm}$ long) and isolated calcite pseudomorphs after evaporite crystals (gypsum?) are dispersed into a dolomicrite matrix (Fig. 9F). The interbedded marl (Mr) have a 
265

266

267

268

269

270

271

272

273

274

275

276

277

278

279

280

281

282

283

284

285

286

287

288

289

290

291

292

293

massive structure and include the same skeletal grains as Lbf lithofacies (i.e., ostracods, charophytes, and fish scales and teeth).

Interpretation. The low biotic diversity and composition (euryhaline organisms such as benthic foraminifera and ostracods) suggest that this facies association was deposited in restricted, marineinfluenced water bodies with rapidly changing salinities. These organisms are adapted to the stressful conditions and are significant producers of carbonate sediments in recent and ancient lagoonal brackish environments (Amstrong and Brasier 2005). Similar biotic associations have been interpreted to develop in ancient coastal lagoonal and peritidal systems (Arribas et al. 1996; López-Martínez et al. 1998, 2006), and in marine-influenced water bodies of ancient coastal wetlands (Suarez-Gonzalez et al. 2015). Clotted to peloidal and filamentous microfabrics suggest microbial-influenced carbonate precipitation. The desiccation cracks and rizoliths, along with black pebbles, are diagnostic of periodical subaerial exposure, suggesting that the shallow marine-influenced water bodies were bordered by palustrine areas. Other early diagenetic processes such as dolomitization and gypsum precipitation are typical components of peritidal environments (Flügel 2010; Warren 2016), and indicate pumping of brackish waters through the original sediment during the last stage of shallowing-upwards elemental sequences. The dolomitization process preserves the depositional texture and is indicative of a very early diagenetic stage.

\subsubsection{Facies Association 4 (FA-4)}

FA-4 occurs mainly in the Rupelo and Arlanzón sections (Fig. 6), and is composed of massive marl and muddy-silty limestone interbedded with well-bedded marly limestone (IMC, Figs. 7, 8E). Muddy-silty limestones (Lb) are parallel laminated wackestone to packstone with unbroken skeletal grains (Fig. 9G), although some Lb beds are grainstone composed of ostracods, intraclasts and peloids (Fig. 9G, H, I). The biotic association includes mostly ostracods and minor charophytes, fish scales and teeth (Fig. 8F and G), and other undifferentiated skeletal grains. The ostracods, largely of one specie, are abundant, vary in average size (between $0.25-0.50 \mathrm{~mm}$ ), and include both smooth and crenulated valves. Micrite matrix is abundant and is peloidal or locally clotted. Micrite is sometimes dolomitized, preserving a fine crystalline depositional texture. Subaerial exposure features such as desiccation cracks, evaporite pseudomorphs (after probable gypsum crystals), rhizoliths, vuggy porosity, and burrowing by Anelidalike forms is observed on top of Lb limestones. 

oligotrophic or brackish water lakes (Flügel 2010). Similar facies associations have been described in ancient lacustrine carbonate successions (Arribas 1986; Platt and Wright 1991; Fregenal-Martínez and Meléndez 1994; Bustillo et al. 2002) and water bodies with no marine influence of carbonate coastal wetland areas (Suarez-Gonzalez et al. 2015). The high abundance and low diversity of ostracods (ostracodite microfacies) is typical of lakes and lagoons (Guernet and Lethiers 1989). On the other hand, the variation in the types of ostracod valves (smooth and crenulated) could indicate changes in water salinity, and temperature (Benson et al. 1961; Canudo 2004). Therefore, oligohaline ostracods (smooth valves) can reflect fresh water (very low salinity conditions) whereas euryhaline ostracods (crenulated valves) are characteristic of brackish waters (Canudo 2004). In addition, the presence of evaporite pseudomorphs as well as dolomite can be indicative of a change in the geochemical composition of the interstitial waters in the last stage of the shallowing-upwards sequences (Bustillo et al. 2002), change that could be related to some, occasional, marine influence. This facies association is interpreted as the result of carbonate sedimentation in shallow and quiet water bodies with no to very little marine influence, which underwent periodical salinity changes, as suggested by the presence of pseudomorphfs after Casulphates and early dolomite precipitation (e.g. Warren 2016). Subaerial exposure would produce desiccation cracks and rizoliths. Ichthyologic remains of this and other facies associations can be tentatively assigned to "Ginglymondy indet." (previously Lepidotes, Pascual-Arribas et al. 2007), which broadly occur in very different environments: saline, brackish, freshwater, continental and coastal (Bermúdez-Rochas 2015).

\subsubsection{Facies Association 5 (FA-5)}

This facies association occurs in Campolara and Hortigüela sections, in the upper part of the San Marcos Formation from the central sector of the study area (Fig. 6, Fig. 8H). FA-5 is composed of marls (MTB) and interbedded carbonate tabular beds (CTB) which commonly are arranged in elemental sequences (Fig. 8H). Carbonate beds have either a massive (Lmd) or a nodular structure (Ln) (Fig. 7). Depositional textures are bioclastic wackestone and packstone with dasycladal skeletal grains (Fig. 10A and B). Clotted to peloidal microfabrics are common and micritic filaments are observed only locally. In addition to dasycladales, which are the most common skeletal grain, the fossil association in Lmd includes charophytes (Fig. 10C and D), ostracods (i.e., disarticulated valves smaller than $0.5 \mathrm{~mm}$, either 
324

325

326

327

328

329

330

331

332

333

334

335

336

337

338

339

340

341

342

343

344

345

346

347

348

349

350

351

352

353

smooth or crenulated), fragments of filamentous calcimicrobial colonies, gastropods and other mollusks. Locally, minute (smaller than $0.1 \mathrm{~mm}$ ), undetermined benthic foraminifera occur. Desiccation cracks, black pebbles and rhizoliths occur on top of some Lmd beds.

Ln limestones show several features and components that destroy the original components and depositional textures. However, some skeletal grains such as dasycladales, charophytes, ostradods, and mollusks (generally gastropods) are evident. Other features include: nodulization, disperse rhizocretions and rhizoliths (Fig. 10E), circumgranular cracks filled with sparry low magnesium calcite cement, microkarst, breccia, and vuggy porosity partly occluded by geopetal infillings. Carbonate nodules include clotted grains, grumelar peloids and micrite nodules.

Interpretation. The fossil content of this facies association is predominantly dasycladales, charophytes, ostracods and gastropods, which point to sedimentation in coastal carbonate water bodies with probable influence of both fresh- and sea-water, as suggested by the presence of both dasycladales and charophytes. Similar facies associations have been described in ancient, very shallow, brackish coastal lagoons periodically affected by subaerial exposure and pedogenesis in palustrine areas (Arribas 1986; Platt and Wright 1991; Fregenal-Martínez and Menéndez 1994; Alonso-Zarza and Wright 2010), as well as in shallow marine-influenced carbonate water bodies in coastal wetland systems (SuarezGonzalez et al. 2015).

\subsubsection{Facies Association 6 (FA-6)}

FA-6 is the most abundant and representative facies association of the San Marcos Formation (Fig. 6). It is composed of interbedded marls (MTB) and carbonate tabular beds (CTB), including both massive (Lm) and nodular limestone (Ln), which form elemental sequences (Figs. 7, 8H). The massive limestones (Lm) are generally marly and consist of mudstone and wackestone. Clotted to peloidal and filamentous microfabrics are common. The fossil association (Fig. 10F, G) includes charophytes, calcimicrobial filaments, ostracods, and mollusks (generally gastropods). Locally, Lm contains only ostracods (ostracodite facies). Also locally, oncoids and dinosaur tracks are observed (Fig. 8I). Massive limestone (Lm) gradually passes upward to nodular limestone (Ln), which has features, such as nodulization, rhizoliths, black pebbles, circumgranular cracks filled by calcite cement, microkarst, and breccia. Furthermore, carbonate nodules and micronodules, clotted grains and grumelar peloids are very common in Ln. In addition, void (channel) argillaceous cutans and geopetal infilled vug pores related to 
354

355

356

357

358

359

360

361

362

363

364

365

366

367

368

369

370

371

372

373

374

375

roots are evident in Ln. Moreover, 0.25-5 mm long, lenticular calcite pseudomorphs after evaporites crystals (probable crystals gypsum) are included in carbonate nodules or dispersed within the micrite matrix (Fig. 10H). All these components and features are similar to those described for Ln lithofacies of the FA-5, which, in fact, is facies change related laterally with FA-6 (Fig. 8H).

Interpretation. The repetitive characteristic sequences of the carbonate tabular beds (massive and nodular limestone) and interbedded marl are similar to those described in fossil shallow carbonate freshwater bodies (Arribas 1986; Platt and Wright 1991; Fregenal-Martínez and Meléndez 1994; Arenas and Pardo 1999; Bustillo et al. 2002; Gierlowsky-Kordesch 2010), which can be associated with coastal environments (Arribas et al. 1996; López-Martínez et al. 1998, 2006; Suarez-Gonzalez et al. 2015). Carbonate sedimentation occurred in shallow freshwater bodies, laterally linked to palustrine areas, and its lateral relationship with FA-5 indicates that sedimentation occurred in water bodies near to other marine-influenced water bodies in a coastal wetland system. The development of pedogenetic elements and features on palustrine limestones $(\mathrm{Ln})$ indicate that these environments were periodically desiccated.

\section{DISCUSSION}

\subsection{General depositional system of the San Marcos Formation}

The temporal evolution of the San Marcos Formation records a transgressive trend: starting with non-marine water bodies surrounded by palustrine environments in the earlier stages, and which were

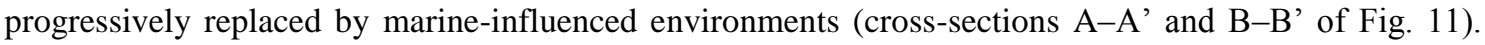
This evolution indicates that during the stages of maximum marine influence, sea-water reached the central part of the studied area, creating a system of shallow and marine-influenced water bodies with carbonate sedimentation (Fig. 11), which received input of fine siliciclastic sediments in its central and southeast part (FA-3 in Fig. 11). This environmental system resulted in the sedimentation of well-bedded, marly, wackestone-packstone limestone and marl with abundant ostracods, benthic foraminifera (dominantly miliolids), scarce charophytes, and fish remains (FA-3). The NW part of this marineinfluenced carbonate system had lower siliciclastic input, allowing the development of meadows of dasycladales, recorded in the sedimentation of massive beds of wackestone-mudstone limestone with dasycladales, charophytes, ostracods, scarce benthic foraminifers, gastropods, and bivalves (FA-5). This 
384

385

386

387

388

389

390

391

392

393

394

395

396

397

398

399

400

401

402

403

404

405

406

407

408

409

410

411

412

413

paleontological association suggests a probable influence of both marine and freshwater, with variable salinity conditions. The shallow marine-influenced water bodies (FA-3 and FA-5) underwent periodic episodes of desiccation and subaerial exposure, as shown by desiccation-cracks in the central and southeastern sector and by pedogenetic calcrete in the northwestern sector. Farther towards the NW (A-A' in Fig. 11), freshwater influence was stronger, as indicated by the higher abundance of charophytes in association with ostracods, gastropods, and bivalves (FA-6). In contrast, towards the SE (A-A' in Fig. 11) marine influence was greater, allowing the development of mixed to muddy siliciclastic tidal flat deposits, consisting of wavy- and flaser-bedded sandstone interbedded with siliciclastic mudstone (FA-2). In turn, this relatively narrow belt of siliciclastic tidal flats connected to the $\mathrm{E}$ with the distal portion of a meandering fluvial system (FA-1 in Fig. 7; FA-1 in Fig. 11). This environmental arrangement of restricted marine-influenced water bodies related to a tidal flat is comparable to that interpreted for the lagoon-tidal flat system of the Middle Jurassic Lajas Formation in the Neuquén Basin (McIlroy et al. 2005; Gugliotta et al. 2015).

To the south of the Jaramillo - Covarrubias fault (cross-section B-B' of Figs. $2 \mathrm{C}$ and 11), sedimentation was dominated mainly by carbonate deposits, suggesting that it was further away from the input of fine siliciclastic sediments during the stage of maximum marine influence. Towards the SE of this area, carbonates precipitated in shallow, marine-influenced water bodies (FA-5), whereas fresh water bodies and palustrine environments (FA-6) accumulated carbonates towards the NW (Fig. 11). Occasional dinosaur tracks mark the top of the palustrine facies (FA-6).

In the isolated outcrop of the Arlanzón Section (AZ in Figs. 2C, 6A), the San Marcos Formation is dominated by FA-4 and interpreted as a mixed carbonate-fine siliciclastic system with very little to no marine influence (Fig. 6A). This area was a small sub-basin and had input of fine siliciclastic sediments from a fluvial system, probably from the south as explained below. Marine influence in this sub-basin is shown by sedimentation of well-bedded wackestone-packstone marly limestone to marl, with abundant ostracods, and scarce charophytes and benthic foraminifera (FA-3 in Fig. 7), as well as by the precipitation of early dolomite and Ca-sulphates. Short desiccation stages affected this area, as evidenced by the presence of desiccation-cracks and gypsum pseudomorphs.

The different facies associations recorded throughout the Berriasian DS3 deposits of W Cameros Basin (Fig. 11) define a complex depositional system composed of many interrelated carbonate and mixed carbonate-siliciclastic environments with contrasting conditions that range from freshwater to tide- 
414 influenced, all surrounded by palustrine areas and located in the continental-marine transition. This 415 complex interrelation of contrasting environments is analogous to that observed in modern wide and flat 416 coastal areas, which are prone to rapid spatial and temporal variations, being easily flooded but also easily 417 desiccated (e.g. Lacovara et al. 2003; Wilkinson and Drummond 2004; Maloof and Grotzinger 2012). The 418 most suitable and widely-used general terminological classification for modern coastal systems with both 419 continental and marine signatures is 'coastal wetlands' (cf. Ramsar Convention 2002; Mendelssohn and 420 Batzer 2006; Baldwin et al. 2009; Wolanski et al. 2009). This term was not commonly used for ancient 421 depositional systems (only sporadically and unsystematically for some fossil coal-bearing transitional 422 units: Greb and DiMichele 2006) until Suarez-Gonzalez et al. (2013, 2015) applied it to the detailed 423 paleoenvironmental classification of complex Lower Cretaceous deposits, similar to those described here, 424 in the neighboring E Cameros Basin. Since then, other ancient deposits, from many different ages and 425 localities, have been observed to match the sedimentological features and criteria proposed by Suarez426 Gonzalez et al. (2015) for ancient coastal wetland depositional systems (Marmi et al. 2014; Costamagna 2016; Di Celma et al. 2016; Fondevilla et al. 2017; Millward et al. 2018). Therefore, given the similarities of all these complex transitional deposits with the Berriasian deposits of the W Cameros Basin described here, it is interpreted that the most appropriate classification for this complex system as a whole is a carbonate coastal wetland.

431

\subsection{General paleogeographic setting of the Berriasian transgresion in the $W$ Cameros Basin}

The sedimentary record of the San Marcos Formation is documented only in the northern sector 
444 intertidal flat rim (FA-2) and with the distal zone of a distributive fluvial system (FA-1). Shallow, marine445 influenced carbonate (FA-5) developed laterally in the areas with minor terrigenous input. The spatial 446 arrangement of the different environments of this coastal system indicates that marine influence may have 447 reached the studied area directly from the north (Figs. 13B, 14), that is, from the BCB (Fig. 1), as 448 previously suggested (Platt and Pujalte 1994). Thus, this arrangement would imply that during the 449 Berriasian, the BCB was interconnected with the northwesternmost sector of the IB (Cm in Fig. 1, WC in 450 Fig. 14), probably by an intermediate system of relatively small basins controlled by extensional tectonics (e.g., Polientes, Sedano, and Rioja Trough Sub-Basins; Klimowitz et al. 1999, 2005; Cámara 1997, 2014; 452 Mas et al. 2002, 2003, 2004). In fact, Benito et al. (2005) noted that, previously, during the Late 453 Kimmeridgian, marine influence reached the Cameros area from the north, and not from the south as it 454 was traditionally considered (Mas et al. 2004 and references therein). These researchers concluded that the northern Boreal realm was nearer to the Cameros area than the southeastern Tethyan realm, and this proximity probably persisted throughout the Upper Jurassic and Early Cretaceous (Quijada et al. 2013a, 2016a, b; Suarez-Gonzalez et al. 2013, 2015, 2016b).

The interpretation of a Berriasian paleogeographic connection between the $\mathrm{W}$ Cameros Basin and the $\mathrm{BCB}$, to the north (Fig. 1), motivates a reconsideration of the general paleogeographic setting of the NE Iberian Peninsula during this period. In previous decades, the interpretation that the northwestern Cameros area belongs to the large-scale tectonic unit of the IB (Fig. 1, Mas et al. 1993; Guimerà et al. 1995; Salas et al. 2001), led Mas et al. (1993, 2002) to suggest that the different marine incursions recorded in the Cameros Basin (during Tithonian-Berriasian and Upper Barremian-Aptian times), reached this basin from the SE (i.e. the Tethyan realm, along the IB). In the case of the Berriasian period, this interpretation was maintained in later works (Mas et al. 2004, 2011), until Quijada et al. (2013a, 2016a, b) presented new data from the E Cameros Basin, which indicated a northern marine link between that basin and the BCB. Nevertheless, these authors did not totally discard the possibility of a marine influence from the SE, through a tentative correlation with the deposits of the Villar del Arzobispo Formation (SouthIberian Basin, Fig. 1), which traditionally were considered Upper Tithonian-Middle Berriasian in age (Aurell et al. 1994; Mas et al. 2004). However, recent studies of the Villar del Arzobispo Formation have brought to light new micropaleontological and stratigraphic data that reassess its age as KimmeridgianTithonian (Campos-Soto et al. 2016, 2017), thus impeding the correlation between this unit and the Berriasian DS 3 deposits of both E and W Cameros Basin. 
Taking all these data into account, the new interpretation of the $\mathrm{W}$ Cameros Berriasian deposits presented

475 here seems to be more consistent with an interpretation of a paleogeographic connection between the

476 Berriasian Cameros Basin and the BCB, rather than with the IB (Fig. 14). The Berriasian BCB shows a

477 transition from continental and coastal deposits in W and SW areas towards clear marine deposits in E and NE areas (Fig. 14; García de Cortázar and Pujalte 1982; Pujalte 1982; Lanaja and Navarro 1987; Pujalte et al. 2004, and references therein). Therefore, during the stage of maximum marine influence in the deposits studied here, both the Berriasian transgression and the syn-sedimentary tectonics (see next section) may have produced the entrance of seawater into the $\mathrm{W}$ Cameros Basin, connecting it to the BCB, in which the Berriasian Aroco and Loma Somera Formations were being deposited (Pujalte 1982; García de Cortázar and Pujalte 1982; Pujalte et al. 2004). Furthermore, the Berriasian deposits of the E Cameros have also been interpreted as paleogeographically connected with coeval BCB deposits (Quijada et al. 2013a, 2016a,b), but there are no preserved outcrops of Berriasian deposits in the linkage zone between them (Fig. 14; Quijada et al. 2013a). Nevertheless, the new results of the W Cameros Basin presented here suggest that perhaps during the stage of maximum marine influence both sub-basins could have been linked paleogeographically as suggested by the siliciclastic tidal flats of the Berriasian Salcedal Formation (W Cameros). These deposits bordered the eastern side of the marine-influenced deposits (FA2 in Fig. 13B), and may have bordered the distal fluvial system towards the east (FA-1 in Fig. 13B), eventually connecting with the siliciclastic tidal flats of the Berriasian Huérteles Formation (Oncala Group) of the E Cameros Basin (Fig. 14; Quijada et al. 2016a).

\subsection{Factors controlling the sedimentation and paleogeography in W Cameros Basin: An example} for interpreting transgressive episodes in the innermost areas of extensional basins.

The main allogenic controls on deposition in intraplate extensional systems are: tectonics, eustasy and climate. Concerning the sedimentation of the W Cameros Basin Berriasian deposits described here, synsedimentary tectonics was a very important factor, because in this area different tectonic structures controlled the thickness and distribution of these deposits. NW-SE normal faults with associated NE-SW transfer zones compartmentalized the N sector of W Cameros Basin in several NW-SE elongated areas with different subsidence rates (framed area in Fig. 12), reflected in different deposit thicknesses. The depocenter (Fig. 4E and F) was located just to the NW of the NE-SW JaramilloCovarrubias Transfer Zone (Fig. 12). The thickness of the studied deposits decreases towards the S of the 

of the San Marcos Formation did not surpass the Jaramillo-Covarrubias Transfer Zone (Fig. 4, and 4 in

506 Fig. 12), indicating that this NE-SW transfer zone also played an important role in its sedimentation.

507 Moreover, several observations are consistent with an interpretation that the fault systems also controlled 508 the distribution of sedimentary environments. In the $\mathrm{N}$ sector, carbonate and mixed depositional 509 environments were bounded by the NE-SW Jaramillo - Covarrubias Transfer Zone. To the SE of this 510 transfer zone, fluvial meandering siliciclastic environments were predominant (Fig. 4; FA-1 in Figs. 13A, 511 B). The shallow, carbonate, water bodies with little to no marine influence and fine siliciclastic input from 512 the E occupied an area near the Jaramillo-Covarrubias Transfer Zone, but did not extend towards the SW 513 beyond the Quintanilla-Hortigüela Fault (FA-4 in Fig. 13A). During the period of maximum marine 514 influence, shallow, marine-influenced carbonates with fine siliciclastic input from the E also occupied an 515 area near the Jaramillo-Covarrubias Transfer Zone, without surpassing the Quintanilla-Hortigüela Fault 516 (FA-3 in Fig. 13B). Distal fluvial meandering streams and a siliciclastic tidal flat occupied the SE area 517 (FA-1 and FA-2 in Fig. 13B). Finally, in the northern Arlanzón sector, the Riocavado de la Sierra Fault 518 (Fig. 2C, 3 in Fig. 12), which crosses the SW of La Demanda Massif (Fig. 2C) and is probably the SE 519 continuation of the Late Variscan Ventaniella Fault of the Cantabrian Mountains (Vegas and Banda 1982; 520 Capote et al. 2002; Suarez-Gonzalez et al. 2016b), seems to have controlled the evolution of the small 521 Arlanzón basin (AZ in Figs. 13A, B), allowing the development of carbonate coastal wetlands during the 522 sedimentation of the San Marcos Formation.

In the W Cameros Basin all these NW-SE and NE-SW tectonic structures have traditionally been 524 interpreted as the product of the reactivation of previous Late Variscan strike-slip faults as normal faults 525 (the NW-SE structures) and transverse faults (the NE-SW structures) during the Late Jurassic - Early 526 Cretaceous extensional phases (Platt 1990, 1995; Arribas et al. 2003; Sacristán-Horcajada et al. 2015). 527 Subsequently, during Alpine contraction, the NW-SE normal faults became thrusts and reverse faults and 528 the NE-SW transverse faults became strike-slip faults (Platt 1990, Guimerà et al. 1995, 2004; Sacristán529 Horcajada et al. 2015). Similarly, the role of reactivated Late Variscan faults has also been shown to be 530 relevant in the sedimentation of Early Cretaceous syn-extensional deposits of the neighboring E Cameros 531 Basin (Suarez-Gonzalez et al. 2016b). The stratigraphic and sedimentological data presented here further 532 support the previous interpretations about the important role of the extensional reactivation of Late 533 Variscan tectonic structures during the sedimentation of the Berriasian W Cameros deposits. In fact, the 
534 role of those structures in the generation of sedimentary basins, at the scale of the whole Iberian Plate, has 535 been recently emphasized in new models of the tectonic evolution of the whole Iberian-European Plate 536 Boundary, both in the Boreal and Tethyan domain, during the Late Jurassic - Early Cretaceous

537

538

539

540

541

542

543

544

545

546

547

548

549

550

551

552

553

554

555

556

557

558

559

560

561

562 extensional phases (Tugend et al. 2014, 2015; Fig. 15).

Therefore, the strong fault control on the facies distribution and thickness of the studied deposits highlights that tectonics was a crucial allogenic factor. Nevertheless, the marine influence in the sedimentation of these deposits also suggests that eustatic variations were a further control in their sedimentation. The stages of marine influence in the San Marcos Formation probably corresponded to the upper Early Berriasian (Subthurmannia occitanica zone) sea level rise and consequent transgressive cycle that occurred in both Boreal and Tethyan European basins ("Middle Berriasian" sensu Hardenbol et al. 1998 who differentiated Early, Middle, and Late Berriasian; and "upper Early Berriasian” sensu Ogg et al. 2008, 2012 who exclusively differentiated Early, and Late Berriasian). Thus, during the stage of maximum marine influence in the $\mathrm{W}$ Cameros Basin, the gains of accommodation linked to a eustatic rise added to that due to gains of tectonic subsidence, increased the total accommodation, and favored marine transgression and the development of a carbonate coastal wetland system (Fig. 13B).

The last factor that may have influenced the sedimentation of the studied deposits is climate. The coastal wetlands of the San Marcos Formation underwent periodically long episodes of desiccation and subaerial exposure, suggesting a semiarid seasonal setting. Moreover, in the neighboring E Cameros Basin, the coeval Berriasian Oncala Group includes tide-influenced fluvial deposits laterally related with thick evaporite deposits, which were partially deposited in extensive, shallow, carbonate-sulphate coastal salinas that received seawater input mostly from the north (Quijada et al. 2013a, b, 2014, 2016a,b). In addition, just north of the W Cameros Basin, in the southernmost part of the BCB, Diéguez et al. (2009) described fossils of xerophytic macroflora in the Aguilar Formation (Upper Tithonian-Lower Berriasian, Pujalte et al. 2004), probably developed in dry-savannah environments. All these observations support the interpretation that the San Marcos Formation coastal wetlands were deposited under a semiarid to arid climate that caused the seasonal alternation of short wet and long dry periods. This interpretation matches the global geological record, which indicates widespread arid conditions across much of Europe at the beginning of the Upper Jurassic, as well as in southern Eurasia during the Upper Jurassic-Early Cretaceous (Hallam 1984, 1985; Hallam et al. 1993; Vakhrameev 1991; Ziegler et al. 1993). 
In summary, during the Berriasian transgressive episode, the combination of tectonics and eustasy, together with climatic factors, led to the establishment of a complex mixed carbonate-siliciclastic coastal wetland system in the W Cameros Basin, which was located at the innermost area of an intraplate extensional system. In the neighboring E Cameros Basin, the Berriasian transgressive episode (Quijada et 567 al. 2013a,b, 2014, 2016a,b), as well as other Early Cretaceous transgressions (Suarez-Gonzalez et al. 2013, 2015), caused the development of complex and wide coastal depositional systems, all of them 569 linked to the influence of marine water coming from the northern BCB. Therefore, the paleogeographic arrangement that allows the development of those complex coastal systems at the innermost part of

571 intraplate extensional basins may be common to many other extensional systems throughout the geological record, and thus, the Cameros Basin may be proposed as a model for the record of

573 transgressive events in the internal areas of those systems, in which the combination of tectonics, eustasy and climate are very likely to produce wide mixed carbonate-siliciclastic-evaporitic coastal systems with a complex mixture of continental and shallow-marine features.

\section{CONCLUSIONS}

A marine transgression reached the $\mathrm{W}$ Cameros Basin during the sedimentation of its Early-

580 Middle Berriasian third depositional sequence (DS 3), which consists of siliciclastic deposits (Salcedal 581 Formation) that gradually change laterally and vertically to carbonate and mixed carbonate-siliciclastic deposits (San Marcos Formation).These units are interpreted as deposited in a complex mixture of carbonate and -siliciclastic environments located in the continental-marine transition, which is interpreted here as a coastal wetland system. A semiarid to arid climate characterized by the seasonal alternation of short wet and long dry periods predominated, causing water bodies of the system to undergo periodic desiccation and subaerial exposure.

The spatial distribution of paleoenvironments indicates that marine influence reached the $\mathrm{W}$

588 Cameros Basin from the Basque-Cantabrian Basin, located to the north. During the maximum marine 589 influence stage (probably the Middle Berriasian global sea level rise), the gains of accommodation linked 590 to a Berriasian eustatic rise was added to the gains of accommodation due to tectonic subsidence, favoring 591 the marine incursion in the $\mathrm{W}$ Cameros Basin. This Early-Middle Berriasian marine influence in the 
592 Cameros Basin exclusively from the north prompts a reevaluation of the general paleogeography of NE 593 Iberian Peninsula for the Berriasian.

594 The establishment of wide and complex coastal wetland systems during the peak of a 595 transgressive episode in the $\mathrm{W}$ Cameros Basin, matches the interpretations of previous studies in 596 neighbouring areas, where also multifaceted coastal systems where recorded during transgressions in the

597

598

599

600

601

602

603

604

605

606

607

608

609

610

611

612

613

614

615

616

617

618

619

620

621 innermost parts of the intraplate extensional basins of the Iberian Plate. Therefore, the development of such complex depositional systems, with both continental and marine signatures, is suggested here to be a result of the interplay between tectonics and eustasy that may be characteristic of internal extensional basins during transgressive periods.

\section{ACKNOWLEDGMENTS}

The authors are grateful to Dr. Ramon Salas and an anonymous referee for their thorough revision of the manuscript. We want to extend our thanks to Dr. Edoardo Perri, Dr. Brian Pratt, and Dr. Gene Rankey as their detailed comments and suggestions have helped us to significantly improve our work. Funding for this research was provided by the Spanish Ministry of Economy and Competitivity, projects CGL2011-22709 and CGL2014-52670-P, and by the research group "Sedimentary Basin Analysis" UCM 910429 of the Complutense University of Madrid, and by the Geosciences Institute (IGEO-CSIC). We thank also the Departments of Geodynamics, Stratigraphy, and Paleontology and Mineralogy and Petrology of the Complutense University of Madrid and the IGEO (CSIC) for their technical support.

\section{REFERENCES}

Allen, P.A., \& Homewood, P. (1984). Evolution and mechanics of a Miocene tidal sandwave. Sedimentology, 31, 63-81.

Alonso-Zarza, A.M., \& Wright, V.P. (2010). Calcretes. In A.M. Alonso-Zarza, and L.H. Tanner (Eds.), Carbonates in Continental Settings: Facies, Environments and Processes (pp. 225-267). Amsterdam: Elsevier. 
Arenas, C., \& Pardo, G. (1999). Latest Oligocene - Late Miocene lacustrine systems of the north-central part of the Ebro Basin (Spain): sedimentary facies model and palaeogeographic synthesis. Palaeogeography, Palaeoclimatology and Palaeoecology, $151,127-148$

Armstrong, H.A., \& Brasier, M. D. (2005). Microfossils. Malden, Blackwell Publishing, 304 p. Arribas, J., Alonso, A., Mas, R., Tortosa, A., Rodas, M., Barrenechea, J.F., Alonso-Azcárate, J., \& Artigas, R. (2003). Sandstone petrography of continental depositional sequences of an intraplate rift basin: Western Cameros Basin (North Spain). Journal of Sedimentary Research, 73, 309-327.

Arribas, M.E. (1986). Petrología y análisis secuencial de los carbonatos lacustres del Paleógeno del sector N de la Cuenca Terciaria del Tajo. Cuadernos de Geología Ibérica, 10, 295334.

Arribas, M.E., Ardèvol, Ll. \& López-Martínez, N. (1996). Lacustrine peritidal carbonates in the Upper cretaceous Tremp Formation (Àger syncline, Pyrenean foreland Basin, Spain). In $17^{\text {th }}$ Regional African European meeting of Sedimentology, Abstracts, p.15.

Arthaud, F., \& Matte, P. (1977). Late Paleozoic strike-slip faulting in southern Europe and northern Africa: result of a right-lateral shear zone between the Appalachians and the Urals. Bulletin of the Geological Association of America, 88, 1305-1320.

Aurell, M., Mas, R., Meléndez, A., \& Salas, R. (1994). El tránsito Jurásico - Cretácico en la Cordillera Ibérica: relación tectónica-sedimentación y evolución paleogeográfica: Cuadernos de Geología Ibérica, 18, 369-396.

Baldwin, A.H., Barendregt, A., \& Whigham, D. (2009). Tidal freshwater wetlands: an introduction to the ecosystem. In A. Barendregt, D. Whigham, and A. Baldwin (Eds.), Tidal Freshwater Wetlands (pp. 1-10). Leiden: Backhuys.

Benito, M.I., Lohmann, K.C., \& Mas, R. (2005). Paleogeography and paleoclimate in the Northern Iberian Basin of Spain: constraints from diagenetic records in reefal and continental carbonates. Journal of Sedimentary Research, 75, 82-96.

Benson, R. H., Berdan J. M., Van den Bold, W. A., Hanai, T., Hessland, l., Howe, H.V., et al., (1961). Part Q, Arthropoda: Crustacea: Ostracoda. In R. C. Moore (Ed.), Treatise on 

University of Kansas Press.

653

654

655

656

657

658

659

660

661

662

663

664

665

666

667

668

669

670

671

672

673

674

675

676

677

678

679

680

Bermúdez-Rochas, D.D. (2015). Ictiofaunas del Cretácico inferior de las cuencas VascoCantábrica y de Cameros en el registro español del Mesozoico - Early Cretaceous Ichthyofaunas from the Basque-Cantabrian and Cameros basins in the Spanish Mesozoic record. Unpublished Ph.D. Thesis. Universidad Complutense de Madrid. Spain. 593 pp.

Beuther, A. (1966). Geologische Untersuchungen in Wealden und Utrillas-Schichten im Westteil der Sierra de los Cameros (Nordwestliche Iberische Ketten). Beihefte zum Geologischen Jahrbuch, 44, 103-121.

Bridge, J. S. (2003). Rivers and Floodplains: Forms, Processes and Sedimentary Record. Oxford, Blackwell, 491 p.

Bridge, J. S. (2006). Fluvial facies models: recent developments. In H. W. Posamentier and R. G. Walker (Eds.), Facies Models Revisited (pp. 85-170). Tulsa: SEPM Special Publication 84.

Bustillo, A., Arribas, M.E. \& Bustillo, M. (2002). Dolomitization and silicification in low-energy lacustrine carbonates (Paleogene, Madrid Basin, Spain). Sedimentary Geology, 151, 107-126.

Cámara, P. (1997). The Basque-Cantabrian basin's Mesozoic tectono-sedimentary evolution. Mémoires de la Société Géologique de France, 171, 187-191.

Cámara, P. (2014). Excursión de Campo. Cuenca Vasco-Cantábrica, Transversal AyoluengoBilbao-Bermeo. Asociación de Geólogos y Geofísicos Españoles del Petróleo, pp. 120.

Campos-Soto, S., Benito, M. I., Mas, R., Caus, E., Cobos, A., Suarez-Gonzalez, P., \& Quijada, I.E. (2016). Revisiting the Late Jurassic-Early Cretaceous of the NW South Iberian Basin: new ages and sedimentary environments. Journal of Iberian Geology, 42, 69-94. Campos-Soto, S., Cobos, A., Caus, E., Benito, M.I., Fernandez-Labrador, L., Suarez-Gonzalez, P., Quijada. I.E., Mas, R., Royo-Torres, R., \& Alcalá, L. (2017). Jurassic Coastal Park: A great diversity of palaeoenvironments for the dinosaurs of the Villar del Arzobispo Formation (Teruel, E Spain). Palaeogeography, Palaeoclimatology, Palaeoecology, 485, 154-177. 
Canudo, J. I. (2004). Ostrácodos. In E. Molina (Ed.), Micropaleontología (pp. 441 - 460). Zaragoza: Prensas Universitarias de Zaragoza.

Capote, R., Muñoz, J. A., Simón, J. L., Liesa, C. L., \& Arlegui, L. E. (2002). Alpine tectonics I: the Alpine system north of the Betic Cordillera. In W. Gibbons and M. T. Moreno (Eds.), The geology of Spain (pp. 367-400). London: Geological Society of London, Special Publication.

Casas-Sainz, A. M., Cortés-Gracia, Á. L., \& Maestro-González, A. (2000). Intraplate deformation and basin formation during the Tertiary within the northern Iberian plate: origin and evolution of the Almazán Basin. Tectonics, 19, 258-289.

Clemente, P. (2010). Review of the Upper Jurassic-Lower Cretaceous stratigraphy in Western Cameros Basin, Northern Spain. Revista de la Sociedad Geológica de España, 23 (3-4), $101-143$

Clemente, P., \& Pérez-Arlucea, M. (1993). Depositional architecture of the Cuerda del Pozo Formation, Lower Cretaceous of the extensional Cameros Basin, north-central Spain. Journal of Sedimentary Petrology, 63, 437-452.

Costamagna, L.G. (2016) The Middle Jurassic Alpine Tethyan unconformity and the Eastern Sardinia - Corsica Jurassic high: A sedimentary and regional analysis. Journal of Iberian Geology, 42, 311-334.

Dalrymple, R.W. (1992). Tidal depositional systems. In R.G. Walker and N.P. James (Eds.), Facies Models: Response to sea level changes (pp. 195-218). St. John's, Newfoundland: Geological Association of Canada.

Dalrymple, R.W. (2010). Tidal depositional systems. In N.P. James and R.W. Dalrymple (Eds.), Facies Models (pp. 201-231). St. John's, Newfoundland: Geological Association of Canada.

Davidson, SK., Hartley, A.J., Weissmann, G.S., Nichols, G.J., \& Scuderi, L.A. (2013). Geomorphic elements on modern distributive fluvial systems. Geomorphology, 180181, 82-95.

DeRaaf, J.F.M., \& Boersma, J.R. (1971). Tidal deposits and their sedimentary structures. Geologie en Mijnbouw, 50, 479-504. 
Di Celma, C., Fagaini, L., Caffau, M. (2016) Marine and nonmarine deposition in a long-term low-accommodation setting: An example from the middle Pleistocene Qm2 unit, eastern central Italy. Marine and Petroleum Geology, 72, 234-253.

Diéguez, C., Hernández, J.M., \& Pujalte, V. (2009). A fern-bennettitalean floral assemblage in Tithonian - Berriasian travertine deposits (Aguilar Formation, Burgos - Palencia, N Spain) and its palaeoclimatic and vegetational implications. Journal of Iberian Geology, 35 (2), 127-140.

Flügel, E. (2010). Microfacies of Carbonate Rocks: Analysis, Interpretation and Application. Heidelberg: Springer, $984 \mathrm{p}$. 
Guernet, C., \& Lethiers, F. (1989). Ostracodes et recherche des milieux anciens: possibilities and limites. Bulletin de la Société géologique de France, 8, 577-588.

Gugliotta, M., Flint, S. S., Hodgson, D. M., \& Veiga, G. D. (2015). Stratigraphic record of riverdominated crevasse subdeltas with tidal influence (Lajas Formation, Argentina). Journal Sedimentary Research, 85, 265-284.

Guimerà, J., Alonso, Á., \& Mas, J. R. (1995). Inversion of an extensional-ramp basin by a newly formed thrust: the Cameros Basin (N. Spain). In J. G. Buchanan and P. G. Buchanan (Eds.), Basin Inversion (pp. 433-453). London: Geological Society, Special Publications, 88 .

Guimerà, J., Mas, R., \& Alonso, Á. (2004). Intraplate deformation in the NW Iberian Chain: Mesozoic extension and Tertiary contractional inversion. Journal of the Geological Society, 161, 291-303.

Hallam, A. (1984). Continental humid and arid zones during the Jurassic and Cretaceous. Palaeogeography, Palaeoclimatology, Palaeoecology, 47, 195-223.

Hallam, A. (1985). A review of Mesozoic climates. Journal of the Geological Society, 142, 433445.

Hallam, A., Crame, J. A., Mancenido, M. O., Francis, J., \& Parrish, J. T. (1993). Jurassic climates as inferred from the sedimentary and fossil record. Philosophical Transactions of the Royal Society of London, B, 341, 287-296.

Hardenbol, J., Thierry, J., Farley, M.B., Jacquin, Th., de Graciansky, P. C., Vail, P.R., et al. (1998). Mesozoic and Cenozoic sequence chronostratigraphic framework of European basins. In P. C. de Graciansky, J., Hardenbol, Th., Jacquin, \& P.R., Vail, (Eds.), Mesozoic-Cenozoic Sequence Stratigraphy of European Basins (pp. 3e13, 763e781, and chart supplements). Tulsa: SEPM Special Publication, 60.

Hartley, A.J., Weissmann, G.S., Nichols, G.J., \& Warwick, G.L. (2010). Large distributive fluvial systems: Characteristics, distribution, and controls on development. Journal of Sedimentary Research, 80, 167-183.

Klein, G. de V. (1985). Intertidal flats and intertidal sand bodies. In R. A. Jr. Davis, (Ed.), Coastal sedimentary environments (pp. 187-224). New York: Springer-Verlag. 
Klein, G.D. (1998). Clastic Tidalites - a partial retrospective view. In C. R. Alexander, R. A. Davis, \& V. J. Henry, (Eds.), Tidalites Processes and Products (pp. 5-14). Tulsa: SEPM, Special Publication, 61.

Klimowitz, J., Malagón, J., Quesada, S., \& Serrano, A. (1999). Desarrollo y evolución de estructuras salinas mesozoicas en la parte suroccidental de la Cuenca Vasco-Cantábrica (norte de España): implicaciones exploratorias. In AGGEP (Ed.), Libro homenaje a José Ramírez del Pozo (pp. 159-166). Madrid: Asociación de Geólogos y Geofísicos Españoles del Petróleo.

Klimowitz, J., Ruíz, G., Hernandez, E., \& Pérez, A. (2005). Caracterización estratigráfica de la serie Purbeck en el área de Polientes-Sedano y las franjas plegadas de Montorio y Zamanzas (Cuenca Cantábrica). In AGGEP (Ed.), Aniversario AGGEP (Libro XXV, pp. 163-168). Madrid: Asociación de Geólogos y Geofísicos Españoles del Petróleo.

Lacovara, K.J., Smith, J.R., Smith, J.B., \& Lamanna, M.C. (2003) The Ten Thousand Islands coast of Florida: a modern analog to low-energy mangrove coasts of Cretaceous epeiric seas. In Davis, R.A., Sallenger, A., and Howd, P. (Eds.), Proceedings of the 5th International conference on Coastal Sediments: New Jersey, World Scientific Publishing, p. 1773-1784.

Lanaja, J.M., \& Navarro, A. (1987). Contribución de la exploración petrolífera al conocimiento de la Geología de España. Madrid: I.G.M.E., 465 p.

Lindholm, R.C., \& Finkelman, R.B. (1972). Calcite staining: semiquantitative determination of ferrous iron. Journal of Sedimentary Petrology, 42, 239-242.

López-Martínez, N., Ardevol, L., Arribas, M.E., Civis, J., \& González-Delgado, A. (1998). The Geological record in non-marine environments around the K/T boundary (Tremp Fm, Spain). Bulletin de la Sociètè géologique de France, 169 (1), 11-20.

López-Martínez, N., Arribas, M.E., Robador, A., Vicens, E., \& Ardèvol, Ll. (2006). Los carbonatos danienses (Unidad 3) de la Formación Tremp (pirineos sur-centrales): paleogeografía y relación con el límite Cretácico-Terciario. Revista de la Sociedad Geológica de España, 19 (3-4), 233-255.

Maloof, A.C. \& Grotzinger, J.P. (2012) The Holocene shallowing-upward parasequence of north-west Andros Island, Bahamas. Sedimentology, 59, 1357-1407. 
Marmi, J., Vila, B., Martín-Closas, C., Villalba-Breva, S. (2014) Reconstructing the foraging environment of the latest titanosaurs (Fumanya dinosaur tracksite, Catalonia). Palaeogeography, Palaeoclimatology, Palaeoecology 410, 380-389.

Martín-Closas, C., \& Alonso, A. (1998). Estratigrafía y biostratigrafía (Charophyta) del 803 Cretácico inferior en el sector occidental de la Cuenca de los Cameros (Cordillera Ibérica). Revista de la Sociedad Geológica de España, 11, 253-270. 

of London, Special Publication, 252.

831

832

833

834

835

836

837

838

839

840

841

842

843

844

845

846

847

848

849

850

851

852

853

854

855

856

857

Mendelssohn, I.A., \& Batzer, D.P. (2006). Abiotic constraints for wetland plants and animals. In D.P., Batzer, and R.R., Sharitz, (Eds.), Ecology of Freshwater and Estuarine Wetlands (pp. 82-114). Berkeley: University of California Press.

Miall, A.D. (2010). Alluvial Deposits. In N.P., James, and R.W., Dalrymple, (Eds.), Facies Models 4 (pp. 105-138). St. John's, Newfoundland: Geological Association of Canada.

Millward, D., Davies, S.J., Williamson, F., Curtis, R., Kearsey, T.I., Bennett, C.E., Marshall, J.E.A., Browne, M.A.E. (2018) Early Mississippian evaporites of coastal tropical wetlands. Sedimentology, doi: 10.1111/sed.12465

Nio, S.D., \& Yang, C.H. (1991). Diagnostic attributes of clastic tidal deposits: a review. In D.G., Smith, G.F., Reinson, B.A., Zaitlin, and R.A., Rahmani, (Eds.), Clastic Tidal Sedimentology (pp. 3-28). C Canadian Society of Petroleum Geologists, Memoir 16.

Norman, ME. (1974). Improved techniques for selective staining of feldspar and other minerals using amaranth. US Geological Survey, Journal Research, 2, 73-79.

Ogg, J.G., Ogg, G., \& Gradstein, F.M. (2008). The Concise Geologic Time Scale. Cambridge: Cambridge University Press, p. 177.

Ogg, J.G., Hinnov, L.A., \& Huang, C. (2012) Cretaceous. In F.M., Gradstein, J.G., Ogg, M.D., Ogg, and G. M., Schmitz, (Eds.), The geologic time scale (pp. 793-853). Amsterdam: Elsevier.

Omodeo-Salé, S., Guimerà, J., Arribas, J., \& Mas, R. (2014). Tectono-stratigraphic evolution of an inverted extensional basin: the Cameros Basin (north of Spain). International Journal of Earth Sciences, 103, 1597-1620.

Pascual-Arribas, C., Sanz-Pérez, E., Hernández-Medrazo, N., \& Latorre Macarrón, P. (2007). Lepidotes sp. en la aloformación Valdeprado del Cretácico Inferior (Berriasiense) de la Cuenca de Cameros (Cordillera Ibérica, Soria, España). Studia Geologica Salmanticensia, 43 (2), 193-206.

Pestrong, R. (1972). Tidal flat sedimentation at Cooley Landing southwest San Francisco Bay. Sedimentary Geology, 8, 251-288. 
Platt, N. H. (1989)a. Continental sedimentation in an evolving rift basin: the Lower Cretaceous of the western Cameros Basin (northern Spain). Sedimentary Geology, 64, 91-109.

Platt, N. H. (1989)b. Lacustrine carbonates and pedogenesis: sedimentology and origin of palustrine deposits from the Early Cretaceous Rupelo Formation, W Cameros Basin, N Spain. Sedimentology, 36, 665-684.

Platt, N. H. (1990). Basin evolution and fault reactivation in the western Cameros basin, Northern Spain. Geological Society of London, Journal, 147, 165-175.

Platt, N. H. (1994). The western Cameros Basin, northern Spain: Rupelo Formation (Berriasian). In E., Gierlowky-Kordesh, and K., Kelts, (Edts.) Global Geological Record of Lake Basins, v. 1 (pp.195-202). Cambridge: Cambridge University Press.

Platt, N.H. (1995). Sedimentation and tectonics of a syn-rift succession: Upper Jurassic alluvial fans and palaeokarst at the late Cimmerian unconformity, Western Cameros Basin, northern Spain. In G., Plint, (Ed.), Sedimentary Facies Analysis (pp. 219-236). Oxford: International Association of Sedimentologists, Special Publication, 22, Blackwell Science.

Platt, N.H., \& Pujalte, V. (1994). Correlation of Upper Jurassic-Lower Cretaceous continental sequences from the southern Biscay margin, northern Spain. Geological Society of London, Journal, 151, 715-726.

Platt, N.H., \& Wright, V.P. (1991). Lacustrine carbonates: facies models, facies distributions and hydrocarbon aspects. In P., Anadón, L., Cabrera, and K., Kelts (Eds.), Lacustrine Facies Analysis (pp. 57-74). Oxford: International Association of Sedimentologists, Special Publication, 13, Blackwell Science.

Pujalte, V. (1982). Tránsito Jurásico-Cretácico, Berriasiense, Valanginiense, Hauteriviense y Barremiense. In A., García (Ed.), El Cretácico de España (pp. 51-63). Madrid: Universidad Complutense de Madrid.

Pujalte, V., Robles, J.C., García-Ramos, J.C., \& Hernández, J.M. (2004). El Malm - Barremiense no marinos en la Cordillera Cantábrica. In J.A., Vera (Ed.), Geología de España (pp. 288-291). Madrid: Sociedad Geológica de España - Instituto Geológico y Minero de España. 
Quijada, I.E., Suarez-Gonzalez, P., Benito, M.I., \& Mas, R. (2013)a. New insights on stratigraphy and sedimentology of the Oncala Group (eastern Cameros Basin): implications for the paleogeographic reconstruction of NE Iberia at Berriasian times. Journal of Iberian Geology, 39, 313-334.

Quijada, I.E., Suarez-Gonzalez, P., Benito, M.I., \& Mas, R. (2013)b. Depositional depth of laminated carbonate deposits: Insights from the Lower Cretaceous Valdeprado Formation (Cameros Basin, Northern Spain). Journal of Sedimentary Research, 83, 241-257.

Quijada, I.E., Suarez-Gonzalez, P., Benito, M.I., Lugli, S., \& Mas, R. (2014). From carbonatesulphate interbeds to carbonate breccias: The role of tectonic deformation and diagenetic processes (Cameros Basin, Lower Cretaceous, N Spain). Sedimentary Geology, 312, 76-98.

Quijada, I.E, Suarez-Gonzalez, P., Benito, M.I., \& Mas, R. (2016)a. Tidal versus continental sandy_muddy flat deposits: Evidence_from_the Oncala Group (Early Cretaceous, N Spain). In B, Tessier, and J.Y., Reynaud (Eds.), Contributions to Modern and Ancient Tidal Sedimentology: Proceedings of the Tidalites 2012 Conference (pp. 133-159). Chichester, West Sussex: International Association of Sedimentologists, Special Publication 47, Wiley Blackwell.

Quijada, I.E., Suarez-Gonzalez, P., Benito, M.I., \& Mas, R. (2016)b. Los isótopos de S en los yesos del Grupo Oncala: evidencia de influencia marina en los depósitos carbonáticoevaporíticos berriasienses de la cuenca de Cameros (La Rioja-Soria). Geo-Temas, 16, $555-558$

Ramsar Convention (2002). Principles and guidelines for incorporating wetland issues into Integrated Coastal Zone Management (ICZM), Resolution VIII.4 (2002), $8^{\text {th }}$ Meeting of the Conference of the Contracting Parties to the Convention on Wetlands, http://www.ramsar.org/sites/default/files/documents/pdf/res/key_res_viii_04_e.pdf.

Reineck, H.E. (1972). Tidal flats. In J. K., Rigby, and W. K., Hamblin (Eds.), Recognition of Ancient Sedimentary Environments (pp. 146 -159). Tulsa: SEPM, Special Publication 16. 
Reineck, H.E., \& Wunderlich, F. (1968). Classification and origin of flaser and lenticular bedding. Sedimentology, 11, 99-104.

Sacristán-Horcajada, S., Mas, J.R., \& Arribas, M.E. (2012)a. Evolución de los sistemas lacustres asociados al estadio temprano de rift en el Semigraben de Rupelo (NO de la Cuenca de Cameros, España): subsidencia e influencia marina. Geo-temas, 13, 89-92. depositional sequence (Lower-middle Berriasian) of the mainly continental synrift sedimentary record in the western Cameros Basin, (N Spain). Abstractbook, $29^{\text {th }}$ IAS Meeting of Sedimentology 2012, Schladming, Austria.

Sacristán-Horcajada, S., Arribas, M.E., \& Mas, J.R. (2012)c. Tipo e intensidad de los procesos pedogenéticos en los sedimentos aluviales y lacustres de la primera secuencia de depósito del Semigraben de Rupelo. Geo-Temas, 13, 112-115.

Sacristán-Horcajada, S., Mas, R., \& Arribas, M.E. (2015). Early syn-rift evolution in the W Cameros Basin (Upper Jurassic, NW Iberian Range) Spain. Journal of Sedimentary Research, 85, 794-819.

Sacristán-Horcajada, S., Arribas, M.E., \& Mas, R. (2016). Pedogenetic calcretes in early syn-rift alluvial systems (Upper Jurassic, West Cameros Basin), Northern Spain. Journal of Sedimentary Research, 86, 794-819.

Salas, R., Guimerà, J., Mas, R., Martín-Closas, C., Meléndez, A., \& Alonso, A. (2001). Evolution of the Mesozoic Central Iberian Rift System and its Cainozoic inversion (Iberian chain). In P.A., Ziegler, W., Cavazza, A.H.F., Robertson, S., Crasquin-Soleau (Eds.), Peri-Tethys Memoir 6: Peri-Tethyan Rift/Wrench Basins and Passive Margins (pp. 145-186). Paris: Mémoires du Museum National d'Histoire Naturelle, 186.

Salomon, J. (1982). El Cretácico inferior de Cameros-Castilla. In A., García (Ed.), El Cretacico de España (pp. 345-387). Madrid: Universidad Complutense de Madrid.

Schudack, M. (1987). Charophytenflora und fazielle Entwicklung der Grenzschichten mariner Jura/Wealden in den Nordwestlichen Iberischen Ketten (mit Vergleichen zu Asturien und Kantabrien). Palaeontographica . Abt. B, 204, 108 p.

Schudack, U. \& Schudack, M. (2009). Ostracod biostratigraphy in the Lower Cretaceous of the Iberian Chain (eastern Spain). Journal of Iberian Geology, 35, 141-168. 
Schudack, U. \& Schudack, M. (2012). Non-Cypridean Ostracoda from the Lower Cretaceous of the Iberian Chain (Spain). Neues Jahrbuch für Geologie und Paläontologie, 266 (3), $251-271$.

Semeniuk V. (1981). Sedimentology and the stratigraphic sequence of a tropical tidal flat, northwestern Australia. Sedimentary Geology, 29, 195-221.

Suarez-Gonzalez, P., Quijada, I.E., Benito, M.I., \& Mas, J.R. (2013). Eustatic versus tectonic control in an intraplate rift basin (Leza Fm, Cameros Basin). Chronostratigraphic and paleogeographic implications for the Aptian of Iberia. Journal of Iberian Geology, 39, $285-312$.

Suarez-Gonzalez, P., Quijada, I.E., Benito, M.I., Mas, J.R., Merinero, R., \& Riding, R. (2014). for a quantitative approach. Sedimentary Geology, 300, 11-27.

Suarez-Gonzalez, P., Quijada, I.E., Benito, M.I., \& Mas, R. (2015). Sedimentology of ancient coastal wetlands: Insights from a Cretaceous multifaceted depositional system. Journal of Sedimentary Research, 85, 95-117.

Suarez-Gonzalez, P., Quijada, I.E., Benito, M.I., \& Mas, R. (2016)a. Do stromatolites need tides to trap ooids? Insights from a Cretaceous system of coastal-wetlands. In B., Tessier, and J.Y., Reynaud (Eds.). Contributions to Modern and Ancient Tidal Sedimentology. Proceedings of the Tidalites 2012 Conference (pp. 161-190).. Chichester, West Sussex: International Association of Sedimentologists, Special Publication 47, Wiley Blackwell.

Suarez-Gonzalez, P., Benito, M.I., Mas, R., Quijada, I.E., \& Campos-Soto, S. (2016)b. Influencia del Keuper y de la estructuración tardivarisca en la arquitectura de las unidades sin-extensionales del borde norte de la Cuenca de Cameros. Geotemas, 16, 185-188.

Tessier, B. (1993). Upper intertidal rhythmites in the Mont-Saint-Michel Bay (NW France): Perspectives for paleoreconstruction. Marine Geology, 110, 355-367.

Thompson, R.W. (1968). Tidal flat sedimentation on the Colorado River Delta northwest Gulf of California. Geological Society of American Memoir 107, 133 p. 

V. (2015). Unusual sauropod tracks in the Jurassic-Cretaceous interval of the Cameros Basin (Burgos, Spain). Journal of Iberian Geology, 41 (1), 141-154.

Tugend, J., Manatschal, G., Kusznir, N.J., Masini, E., Mohn, G., \& Thinon, I. (2014). Formation and deformation of hyperextended rift systems: Insights from rift domain mapping in the Bay of Biscay-Pyrenees. Tectonics, doi: 10.1002/2014TC003529

Tugend, J., Manatschal, G., \& Kusznir, N.J. (2015). Spatial and temporal evolution of hyperextended rift systems: Implication for the nature, kinematics, and timing of the Iberian-European plate boundary. Geology, 43, 15-18.

Vakhrameev, V. A. (1991). Jurassic and Cretaceous floras and climates of the Earth. Cambridge: Cambridge University Press, 318 p.

Vegas, R., \& Banda, E. (1982). Tectonic framework and Alpine evolution of the Iberian Peninsula. Earth Evolution Sciences, 4, 320-343.

Warren, J.K. (2016). Evaporites: A geological compendium. Springer, Cham, 1813 pp.

Weissmann, G.S., Hartley, A.J., Nichols, G.J., Scuderi, L.A., Olson, M., Buehler, H., and Banteah, R. (2010). Fluvial form in modern continental sedimentary basins: Distributive fluvial systems. Geology, 38, 39-42.

Wilkinson, B.H. \& Drummond, C.N. (2004) Facies mosaics across the Persian Gulf and around Antigua: stochastic and deterministic products of shallow-water sediment accumulation. Journal of Sedimentary Research, 74, 513-526.

Wolanski, E., Brinson, M.M., Cahoon, D.R., \& Perillo, G.M.E. (2009). Coastal wetlands: a synthesis. In G.M.E., Perillo, E., Wolanksi, D.R., Cahoon, and M.M., Brinson (Eds.), Coastal Wetlands (pp. 1-62). Amsterdam: Elsevier.

Ziegler, A. M., Parrish, J.M., Jiping, Y., Gyllenhaal, E. D., Rowley, D. B., Parrish, J. T., Shangyou, N. Bekker, A., \& Hulver, M. L. (1993) Early Mesozoic Phytogeography and Climate. Philosophical Transactions. Biological Sciences, 341, 297-305.

1000

1001

1002

1003 
Figure 1: A) The Cameros Basin $(\mathrm{Cm})$ in the geological setting of the Iberian Peninsula, 1007 showing its location in relation to the two main Mesozoic intraplate extensional systems of the plate: the 1008 Basque-Cantabrian Basins Extensional System (BCB) and the Iberian Basins Extensional System (IB) 1009 (modified from Mas et al., 2004). B) Major cycles or megasequences in the Cameros area of the Basin 1010 Iberian Basins Extensional System (IB) (modified from Mas el al. 2011).

1011

1012

1013

1014

1015

1016

1017

1018

1019

1020

1021

1022

1023

1024

1025

1026

1027

1028

1029

1030

1031

1032

Figure 2: A) Geological map of the Cameros Basin (modified from Mas et al. 2002, 2003) showing the location of the geological cross sections of Fig. 2B and the studied area (shown in detail in Fig. 2C). B) Geological cross sections of the Cameros Basin (1 - 1', 2 - 2' and 3 - 3') (modified from Guimerà et al. 1995, and Mas et al. 2003). C) Geological map of the West Cameros Basin (modified from Mas et al. 2002, 2003) showing the location of the stratigraphic sections in this work [Arlanzón (AZ), Torrelara (TO), Paules (PA), Aceña (AC), Morrión (MO), Rupelo (RU), San Millán (SM), Cubillejo (CU), Quintanilla (QU), Campolara (CA), Hortigüela (HO), Vizcainos (VZ), Jaramillo Quemado (JQ), Pinilla de los Moros (PM), Castrovido (CTV), Terrazas 2 (TR2), Terrazas 1 (TR1), Moncalvillo (MN), Arroyo del Helechal (AHE), Mamolar Norte (MAN), Mamolar Sur (MAS), Pinilla de los Barruecos (PI), La Gallega Sur (GAS), Talveila (TAL), Doña Santos (DS), Camino Forestal (CF), Área Recreativa (AR), Brezales (BR) and Espejón (ES)]. See cross correlations in Fig. 5 (A-A', B-B'and C-C').

Figure 3: A) General stratigraphic record of the Cameros Basin (modified from Mas et al. 2004, 2011); DS, depositional sequences (1 - 8); red rectangle indicates the Tithonian - Berriasian stratigraphic record in the studied sector. B) Stratigraphic framework of the sedimentary record of the W Cameros Basin (modified from Arribas et al. 2003); the red rectangle indicates the focus depositional sequence (DS $3)$.

Figure 4: Thickness distribution of the Tithonian - Berriasian formations in the study sections. A) Brezales Fm (DS 1); B) Boleras Fm (DS 1); C) Jaramillo Fm (DS 2); D) Campolara Fm (DS 2); E) Salcedal Fm (DS 3); F) San Marcos Fm (DS 3). The size of the black circles is directly proportional to the thickness in each section (also expressed numerically). Cross-correlations A - A' and B-B' (in Fig. 2C, 
1033

1034

1035

1036

1037

1038

1039

1040

1041

1042

1043

1044

1045

1046

1047

1048

1049

1050

1051

1052

1053

1054

1055

1056

1057

1058

1059

1060

1061

Figure 5: Cross-correlations ( $\mathrm{A}-\mathrm{A}^{\prime}, \mathrm{B}-\mathrm{B}^{\prime}$, and $\mathrm{C}-\mathrm{C}^{\prime}$ ) showing the distribution of the depositional sequences (DS 1, DS 2, and DS 3) and their corresponding formations. Cross-correlations A - A' and B - B' (Fig. 2C, Fig. 4, and Fig. 5) for the stratigraphic sections of the North Sector of the West Cameros Basin, and cross-correlation C-C'(Fig. 2C, Fig. 4, Fig. 5) of its south sector.

Figure 6: Representative stratigraphic sections of the facies recorded in the third depositional sequence (DS 3) of the Tithonian-Berriasian record. Upper part: Sections located in cross-correlation A A' (Fig. 2C, Fig. 4, and Fig. 5) and Arlanzón section. Lower part: Sections located in cross-correlation B - B' (Fig. 2C, Fig. 4, and Fig. 5).

Figure 7: Architectural elements and facies associations (FA) distinguished in the third depositional sequence (DS 3) of the Tithonian-Berriasian record in the study area. The letters of facies in each FA refer to the lithofacies described in Table 2. Legend as in Fig. 6.

Figure 8: Field photographs of facies and facies associations. A) Fluvial paleo-channel $(\mathrm{CH})$ with lateral accretion (LA) and floodplain fines (FF) in FA-1, Salcedal Fm, CTV section. B) Siliciclastic tidal flat facies (Srf and Fm) in FA-2, Salcedal Fm, CTV section. C) Lbf, and Mr facies of FA-3, interpreted as having been deposited in marine-influenced water bodies, San Marcos Fm, RU section. D) Desiccation cracks on top of Lbf facies of FA-3 deposits (marine-influenced water bodies), San Marcos Fm, RU section. E) Lb, and Mr facies of FA-4, interpreted as deposits of water bodies with no to very little marine-influence, San Marcos Fm, SM section (arrow length 3 m). F) Detail of fish scale in FA-4, San Marcos Fm, RU section. G) Detail of fish teeth in FA-4, San Marcos Fm, SM section. H) Sequences of FA-5 facies (deposits of marine-influenced water bodies to palustrine settings) overlying FA-6, San Marcos Fm, CA section (arrow length $7 \mathrm{~m}$ ). I) Dinosaur footprints on palustrine carbonates (Ln) on top of FA-6, San Marcos Fm, QU section (small wall height $0.6 \mathrm{~m}$ approx.). 
Figure 9: Microscopic character of facies and components. A) Wackestone with miliolid

1063

1064

1065

1066

1067

1068

1069

1070

1071

1072

1073

1074

1075

1076

1077

1078

1079

1080

1081

1082

1083

1084

1085

1086

1087

1088

1089

1090

1091 foraminifera and ostracods, Lbf facies in FA-3, San Marcos Fm, RU section. B) Wackestone with ostracod valves showing "cup-in-cup" arrangement and miliolid foraminifera, Lbf facies in FA-3, San Marcos Fm, RU section. C) Detail of a miliolid section, Lbf facies in FA-3, San Marcos Fm, RU section. D) and E) Wackestone with minute foraminifera (white arrows) and ostracods, Lbf facies in FA-3, San Marcos Fm, AZ section. F) Calcite pseudomorphs (white arrows) after evaporite crystals (lenticular gypsum?) within a dolomicrite matrix, Lbf facies in FA-3, San Marcos Fm, RU section. G) Wackestone with ostracods, Lb facies in FA-4, San Marcos Fm, RU section. H) Wackestone - packstone with ostracods and micritic nodular-brecciated structure, Lb facies in FA-4, San Marcos Fm, RU section. I) Wackestone - packstone with ostracods, Lb facies in FA-4, San Marcos Fm, RU section.

Figure 10: Microscopic character of facies and components. A) and B) Detailed section of a specimen of dasycladales, Lmd facies in FA-5, San Marcos Fm, HO section. C) Wackestone with dasycladales, charophytes and ostracods, Lmd facies in FA-5, San Marcos Fm, HO section. D) Detailed section of a charopyte thallus, Lmd facies in FA-5, San Marcos Fm, HO section. E) Alveolar (rhizoliths) and clotted microfabrics in a pedogenetic calcrete, Ln in FA-6, San Marcos Fm, PA section. F) Peloidal wackestone - packstone with charophytes and ostracods, Lm facies in FA-6, San Marcos Fm, HO section. G) Mudstone - wackestone with peloids, ostracods and charophytes, Lm facies in FA-6, San Marcos Fm, CA section. H) Calcite pseudomorphs (white arrows) after evaporite crystals (probable gypsum) in a carbonate nodule and within the micrite matrix, Ln in FA-6, San Marcos Fm, PA section.

Figure 11: Schematic interpretive framework of the facies associations and depositional environments during maximum marine influence of the San Marcos Fm. This framework is based on the correlation of the stratigraphic sections of the cross-sections A - A' and B - B' (see their locations in Figures 2C, 4, 5, and 6).

Figure 12: Schematic map of the study area (W Cameros Basin) showing the distribution of stratigraphic sections recording the third depositional sequence (DS 3; white circles in the rectangleframed area), and also showing the main paleo-faults that may have controlled the sedimentation in the western sector of the "Cameros tectonic Unit" (sensu Mas et al. 2002, 2003). 
Figure 13: Interpretive paleogeographic distribution and evolution of the study area (location 1094 shown by the rectangle-framed area of Fig. 12) during deposition of the San Marcos Fm. A) Schematic

1095

1096

1097

1098

1099

1100

1101

1102

1103

1104

1105

1106

1107

1108

1109

1110

1111

1112

1113

1114

1115

1116

1117

1118

1119

1120

1121

Figure 14: Paleogeographic reconstruction during the "Berriasian transgression" (Lower Middle? Berriasian) in the extensional basins of the Iberian Plate (North and East of Iberia). These features are indicated showing the location and main facies of Berriasian deposits in the North and East of the Iberian Peninsula $. \mathrm{BC}=$ Basque-Cantabrian Basin $(N C P=$ Norcastilian Platform, $N C T=$ Navarrese Cantabrian Trough, $\mathrm{BA}=$ Basque Arch); $\mathrm{WC}=$ West Cameros Basin; $\mathrm{EC}=$ East Cameros Basin; $\mathrm{CI}=$ Central Iberian Range; SI = South Iberian Basin; WM = West Maestrat Basin; EM = East Maestrat Basin; CC = Catalonian Coastal Ranges; $\mathrm{P}=$ Pyrenean Basin (modified from Quijada et al. 2013a).

Figure 15: Reconstruction of the Upper Jurassic - Lower Cretaceous paleotectonic setting along the Iberian-European plate boundary when the maximum extent of Berriasian transgression reached the Cameros Basin from the north. BoBP $=$ Bay of Biscay - Parentis rift system, $\mathrm{PBC}=$ Pyrenean - BasqueCantabrian rift systems; $\mathrm{IB}=$ Iberian intraplate extensional basins system, $C C=$ Catalonian Coastal Ranges (modified from Tugend et al. 2015).

Table 1. Stratigraphy and general characteristics of the Tithonian - Berriasian depositional sequences (DS 1, DS 2 and DS 3) in the W Cameros Basin. (* This study - see DS 3 Formations). For brevity, throughout this article, the authors have used the names of the Tithonian - Berriasian Formations in their shortest form: Brezales Fm (Señora de Brezales Fm), Boleras Fm, Jaramillo Fm (Jaramillo de la Fuente Fm), Campolara Fm, Salcedal Fm (Río del Salcedal Fm), and San Marcos Fm (Río de San Marcos Fm).

Table 2. DS 3 Lithofacies (siliciclastic facies code follows Miall 2010). 
Table 1. Stratigraphy and general characteristics of the Tithonian - Berriasian Depositional Sequences (DS 1, DS 2 and DS 3) in the West Cameros Basin. (* This study - see DS 3 Fms).

\begin{tabular}{|c|c|c|}
\hline $\begin{array}{c}\text { Depositional } \\
\text { Sequences }\end{array}$ & Age & Formations. General characteristics. \\
\hline \multirow{2}{*}{ DS 3} & \multirow{4}{*}{ 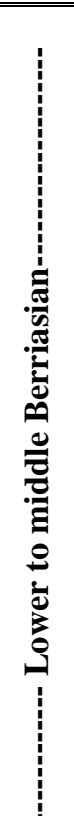 } & $\begin{array}{l}\text { Río de San Marcos Fm (also San Marcos Fm). - The San Marcos Fm is } 0 \text { to } 84 \\
\text { m thick and consists of limestone (mainly mudstone and wackestone), often silty, well- } \\
\text { bedded, and alternating with marl. Its fossil content consists of ostracods, charophytes, } \\
\text { benthic foraminifers (mainly miliolids), dasycladales*, fish remains, gastropods and } \\
\text { bivalves. It corresponds to a carbonate coastal wetland }^{*} \text { depositional system. The Pinilla } \\
\text { de los Moros Fm (DS 6.1, Hauterivian - Barremian aged) unconformable lies on this } \\
\text { Formation (Fig. 5). }\end{array}$ \\
\hline & & $\begin{array}{l}\text { Río del Salcedal Fm (also Salcedal Fm). - The Salcedal Fm is } 0 \text { to } 69 \mathrm{~m} \text { thick and } \\
\text { consists mainly of lenticular bodies of sandstone, and silty and sandy mudstone, and in } \\
\text { its uppermost part thin alternating sheets of flaser-bedded sandstone and silty mudstone } \\
\text { It corresponds mainly to a meandering fluvial system, and its uppermost part to a } \\
\text { siliciclastic tidal flat }\end{array}$ \\
\hline \multirow[b]{2}{*}{ DS 2} & & $\begin{array}{l}\text { Campolara Fm. - The Campolara Fm is } 0 \text { to } 56 \mathrm{~m} \text { thick and consists of limestone } \\
\text { (mudstone, wackestone and packstone), often nodular, and marl, displaying paleosols, } \\
\text { with charophytes, ostracodes, and gastropods. It corresponds to shallow lacustrine to } \\
\text { palustrine depositional systems. }\end{array}$ \\
\hline & & $\begin{array}{l}\text { Jaramillo de la Fuente Fm (also Jaramillo Fm). - The Jaramillo Fm is } 0 \text { to } 380 \mathrm{~m} \\
\text { thick and consists of lenticular bodies of sandstone, silty and sandy mudstone, and some } \\
\text { intercalations of limestone interpreted as deposited in a fluvial system with meandering } \\
\text { channels, traversing clayey floodplains with zones of shallow ephemeral lakes. It } \\
\text { changes gradually both vertically and laterally into the Campolara Fm. }\end{array}$ \\
\hline \multirow[b]{2}{*}{ DS 1} & & $\begin{array}{l}\text { Boleras Fm. - The Boleras Fm is } 0 \text { to } 116 \mathrm{~m} \text { thick and consists of limestones } \\
\text { (mudstone, wackestone, and packstone) with charophytes, ostracods, gastropods, and } \\
\text { bivalves. Being interpreted as deposited in lacustrine - palustrine systems. Pedogenic } \\
\text { modifications (pedogenic calcretes) are characteristic. In the South Sector (Fig.2C, Fig. } \\
\text { 5), the Peñacoba Fm (DS 5, Valanginian - Hauterivian, NW area of the South Sector) or } \\
\text { the Pinilla de los Moros Fm (DS 6.1, Hauterivian - Barremian, SE area of the South } \\
\text { Sector) unconformable overlie on DS 1. These Fms overlie the Boleras Fm, or if the } \\
\text { latter is absent, the Brezales Fm. }\end{array}$ \\
\hline & : & $\begin{array}{l}\text { Señora de Brezales Fm (also Nuestra Señora de Brezales Fm and Brezales } \\
\text { Fm). - The Brezales Fm overlies a major unconformity that developed on pre-rift } \\
\text { marine Callovian to Kimmeridgian sandstones and limestones. In the North and Central } \\
\text { sectors of the West Cameros Basin (Fig.2C, Fig. 5); this unconformity developed over } \\
\text { the Callovian limestones and sandy limestones (Pozalmuro Fm, defined by Wilde 1990). } \\
\text { In the south sector of the study area, the unconformity developed over the Middle-Upper } \\
\text { Jurassic sandstones and conglomerates. The Brezales Fm is } 0 \text { to } 222 \text { m thick and consists } \\
\text { of conglomerates, sandstones, sandy mudstones, and sandy limestones deposited in } \\
\text { alluvial systems (alluvial and fluvial fans). Pedogenic modifications (pedogenic } \\
\text { calcretes) are common. It changes gradually both vertically and laterally into the Boleras } \\
\text { Fm. }\end{array}$ \\
\hline
\end{tabular}


Table 2. DS 3 Lithofacies (siliciclastic facies code follows Miall, 2010).

\begin{tabular}{|c|c|c|c|}
\hline $\begin{array}{l}\text { Facies } \\
\text { code }\end{array}$ & - Lithofacies & $\begin{array}{l}\text { Sedimentary structures or textural } \\
\text { organization and microfabrics }\end{array}$ & Interpretation \\
\hline \multicolumn{4}{|c|}{ Siliciclastic lithofacies } \\
\hline$\overline{\text { St }}$ & $\begin{array}{l}\text { sandstone (subarkose), fine to coarse } \\
\text { grained }\end{array}$ & solitary or grouped trough crossbeds & $\begin{array}{l}\text { sinuous-crested and linguoid (3-D) } \\
\text { dunes }\end{array}$ \\
\hline $\mathbf{S r}$ & $\begin{array}{l}\text { sandstone (subarkose), very fine to } \\
\text { fine grained }\end{array}$ & $\begin{array}{l}\text { ripple cross-lamination (occasionally } \\
\text { climbing) }\end{array}$ & ripples (lower flow regime) \\
\hline Srf & $\begin{array}{l}\text { sandstone (subarkose), very fine to } \\
\text { fine grained and thin interbedded dark } \\
\text { grey siliciclastic mudstone }\end{array}$ & flaser bedding & $\begin{array}{l}\text { mud-draped current and wave ripples; } \\
\text { alternating bed-load traction and } \\
\text { suspended-load settling; tidal? }\end{array}$ \\
\hline Sh & $\begin{array}{l}\text { sandstone (subarkose), very fine to } \\
\text { medium grained }\end{array}$ & $\begin{array}{l}\text { horizontal lamination, parting or streaming } \\
\text { lineation }\end{array}$ & plane-bed flow (super-critical flow) \\
\hline $\mathbf{F m}$ & $\begin{array}{l}\text { siliciclastic mudstone; occasionally } \\
\text { sandy or marly siltstone; usually } \\
\text { reddish and occasionally dark grey }\end{array}$ & $\begin{array}{l}\text { massive, desiccation cracks, roots traces, } \\
\text { bioturbation, carbonate nodules; } \\
\text { occasionally ripple cross-laminated thin } \\
\text { layers intercalated }\end{array}$ & $\begin{array}{l}\text { overbank, root bed, incipient soil; } \\
\text { occasionally ripples (lower flow } \\
\text { regime) }\end{array}$ \\
\hline \multicolumn{4}{|c|}{ Carbonate and mixed carbonate-siliciclastic lithofacies } \\
\hline$\overline{\mathbf{L b}}$ & $\begin{array}{l}\text { well-bedded marly limestone, } \\
\text { sometimes dolomitic; abundant } \\
\text { ostracods, some charophytes, and fish } \\
\text { scales and teeth }\end{array}$ & $\begin{array}{l}\text { marly wackestone-mudstone, packstone, } \\
\text { occasionally dolomitic; common clotted- } \\
\text { peloidal microfabrics; locally gypsum } \\
\text { pseudomorphs; unfragmented microfossils; } \\
\text { desiccation cracks, bioturbation, no } \\
\text { pedogenic features }\end{array}$ & $\begin{array}{l}\text { carbonate (partly microbialitic) and } \\
\text { mixed carbonate-siliciclastic muddy } \\
\text { sediment deposited in a quiet, shallow } \\
\text { water body with none or very little } \\
\text { marine influence }\end{array}$ \\
\hline Lbf & $\begin{array}{l}\text { well-bedded marly limestone, } \\
\text { sometimes dolomitic; ostracods, } \\
\text { benthic foraminifera, occasional } \\
\text { charophytes, and fish scales and teeth }\end{array}$ & $\begin{array}{l}\text { marly wackestone-mudstone, packstone, } \\
\text { occasionally dolomitic; common clotted- } \\
\text { peloidal microfabrics; locally gypsum } \\
\text { pseudomorphs; unfragmented microfossils; } \\
\text { desiccation cracks, bioturbation, no } \\
\text { pedogenic features }\end{array}$ & $\begin{array}{l}\text { carbonate (partly microbialitic) and } \\
\text { mixed carbonate-siliciclastic muddy } \\
\text { sediment deposited in a quiet, shallow } \\
\text { coastal marine-influenced water body }\end{array}$ \\
\hline $\mathbf{L m}$ & $\begin{array}{l}\text { massive limestone, generally marly; } \\
\text { charophytes (gyrogonites and thalli), } \\
\text { ostracods, gastropods, bivalves; } \\
\text { occasionally oncoliths and dinosaur } \\
\text { foot prints }\end{array}$ & $\begin{array}{l}\text { mudstone, wackestone, commonly marly; } \\
\text { common clotted-peloidal microfabrics; very } \\
\text { rare gypsum pseudomorphs; bioturbation, } \\
\text { subaerial exposure, especially desiccation } \\
\text { cracks }\end{array}$ & $\begin{array}{l}\text { muddy carbonate sediment (partly } \\
\text { microbialitic) deposited in a shallow, } \\
\text { quiet water body with none or very } \\
\text { little marine influence }\end{array}$ \\
\hline Lmd & $\begin{array}{l}\text { massive limestone, generally marly; } \\
\text { charophytes (gyrogonites and thalli), } \\
\text { filamentous calcimicrobes, ostracods, } \\
\text { dasycladales, } \underline{\text { scarce benthic }} \\
\text { foraminifera, gastropods, bivalves }\end{array}$ & $\begin{array}{l}\text { mudstone, wackestone, commonly marly; } \\
\text { common clotted-peloidal and filamentous } \\
\text { microfabrics; bioturbation, subaerial } \\
\text { exposure, especially desiccation }\end{array}$ & $\begin{array}{l}\text { muddy carbonate sediment (partly } \\
\text { microbialitic) deposited in a shallow, } \\
\text { quiet, and brackish coastal marine- } \\
\text { influenced water body }\end{array}$ \\
\hline Ln & $\begin{array}{l}\text { nodular limestone, intraclasts, black } \\
\text { pebbles; scarce charophytes, } \\
\text { ostracods, gastropods, bivalves }\end{array}$ & $\begin{array}{l}\text { original textures rarely preserved, intense } \\
\text { pedogenic modification (desiccated, } \\
\text { brecciated and nodular microfabrics) }\end{array}$ & $\begin{array}{l}\text { carbonate sediment deposited in } \\
\text { shallow water bodies with none or very } \\
\text { little marine influence and palustrine } \\
\text { environments affected by periodical } \\
\text { desiccation and pedogenesis }\end{array}$ \\
\hline Mr & $\begin{array}{l}\text { massive marl and muddy-silty } \\
\text { limestone; ostracods, charophytes, } \\
\text { fish scales and teeth; usually dark } \\
\text { gray }\end{array}$ & $\begin{array}{l}\text { marl and marly mudstone, fines siliciclastic } \\
\text { and muddy carbonate; bioturbation and } \\
\text { occasionally carbonate nodules, calcretes, } \\
\text { root traces }\end{array}$ & $\begin{array}{l}\text { siliciclastic - carbonate muddy sediment } \\
\text { deposited in quiet, shallow, water } \\
\text { bodies both with no or very little } \\
\text { marine influence and with marine } \\
\text { influence; locally moderate to intense } \\
\text { pedogenic features linked to sub-aerial } \\
\text { exposure }\end{array}$ \\
\hline $\mathbf{P}$ & $\begin{array}{l}\text { paleosol carbonate (pedogenic } \\
\text { calcrete) }\end{array}$ & $\begin{array}{l}\text { pedogenic microfabric and features: } \\
\text { filaments, mootling, desiccation, nodules, } \\
\text { lamination, brecciation, pseudomicrokarst } \\
\text { cavities, pedotubules, rhizocretions }\end{array}$ & $\begin{array}{l}\text { pedogenic secondary carbonate } \\
\text { displacive precipitation }\end{array}$ \\
\hline
\end{tabular}




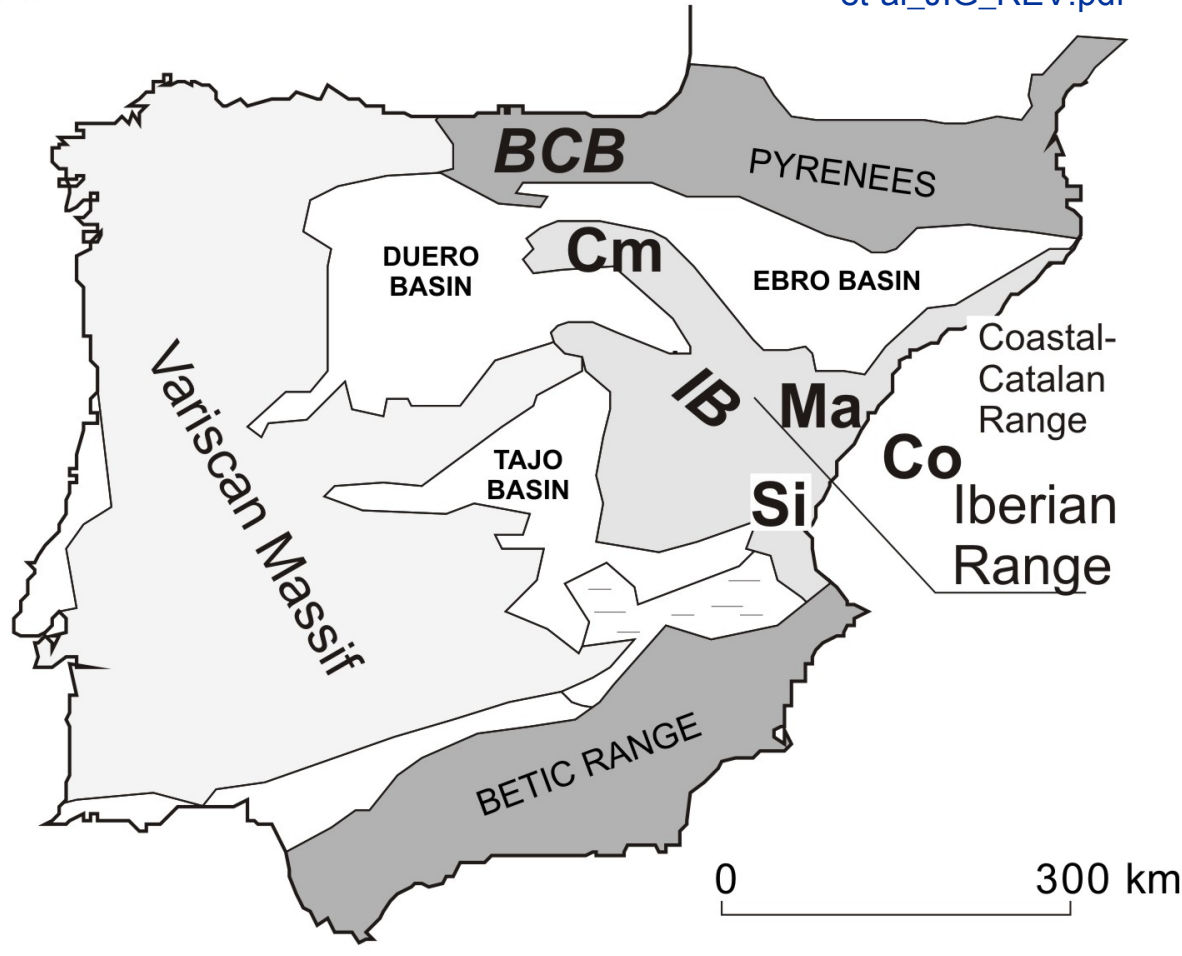

Alpine Belts

Intracratonic Belts

Cenozoic Basins

Tabular Cover
$B C B$ - Basque-Cantabrian Basins Extensional System

IB - Iberian Basins Extensional System

$\mathrm{Cm}$ - Cameros Basin

Ma - Maestrat Basin

Si - South-Iberian Basin

Co - Columbrets Basin

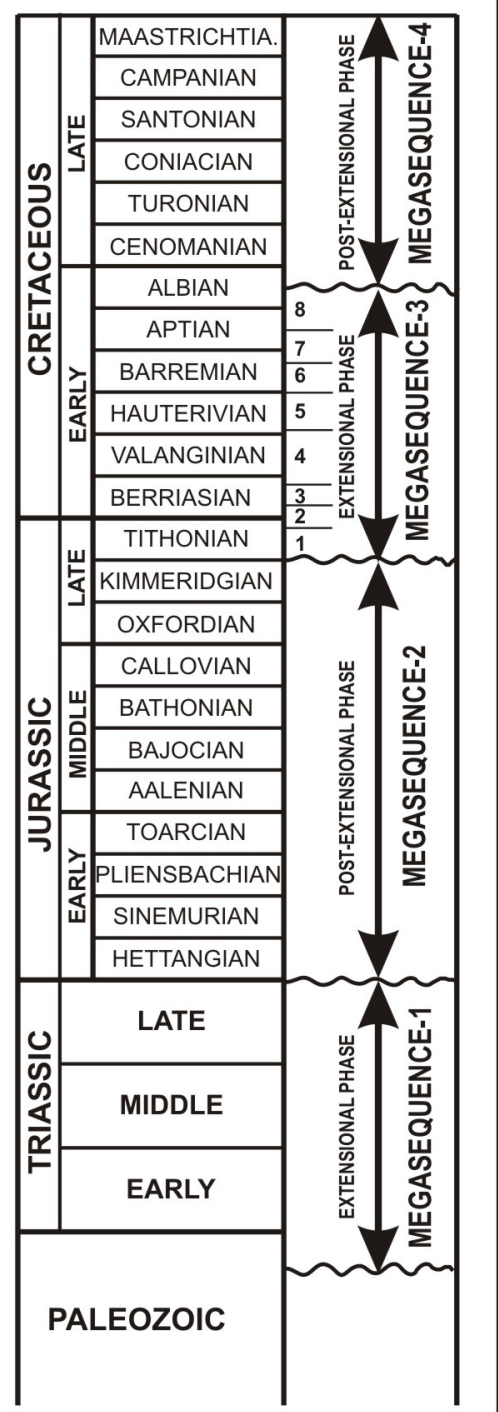

1 to $8=$ CAMEROS BASIN DEPOSITIONAL SEQUENCES 

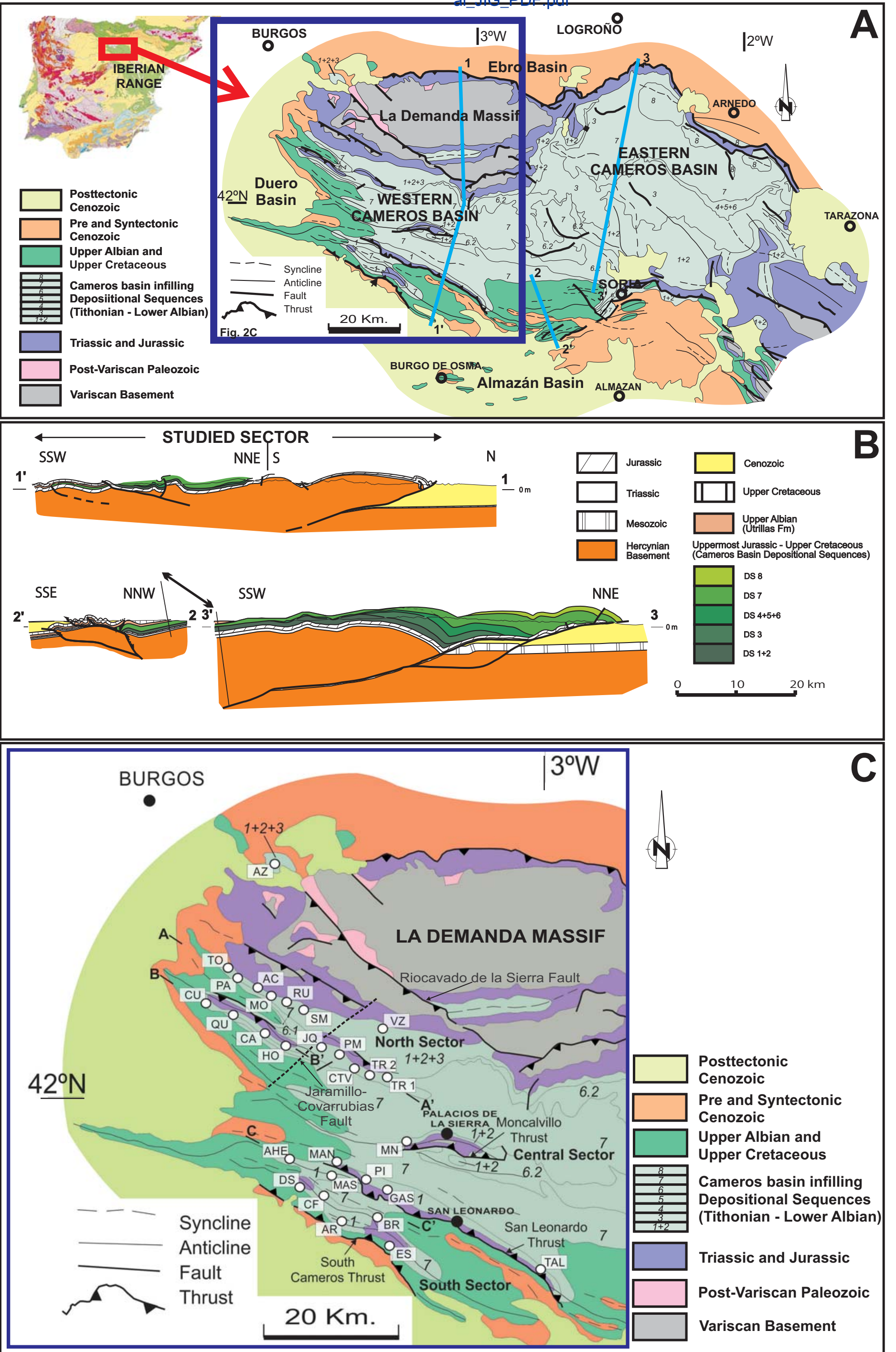

Posttectonic

Cenozoic

Pre and Syntectonic

Cenozoic

Upper Albian and Upper Cretaceous

Cameros basin infilling Depositional Sequences (Tithonian - Lower Albian)

Triassic and Jurassic

Post-Variscan Paleozoic

Variscan Basement 
Click here to access/download;Figure;Fig_03_Mas-et-

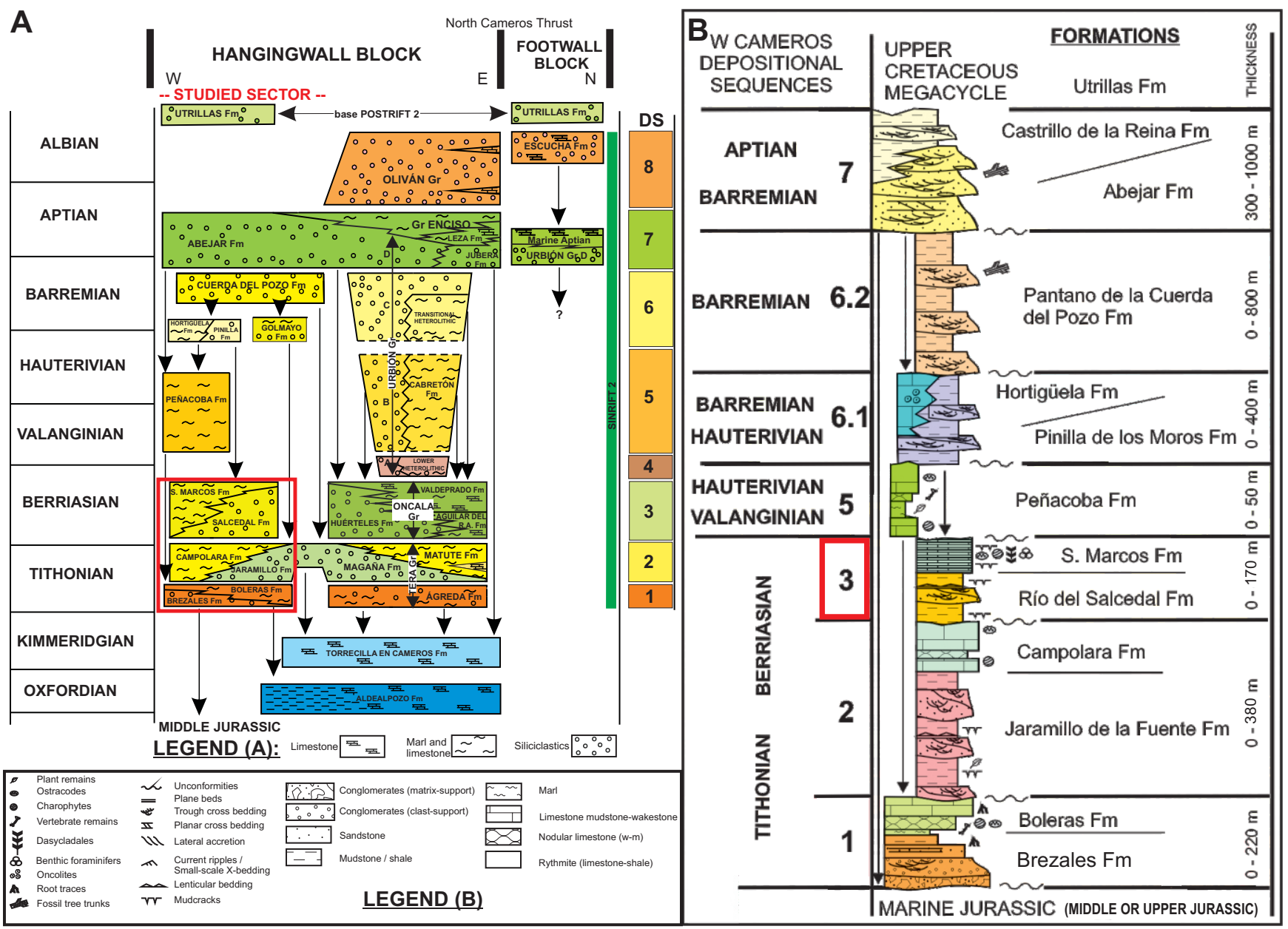



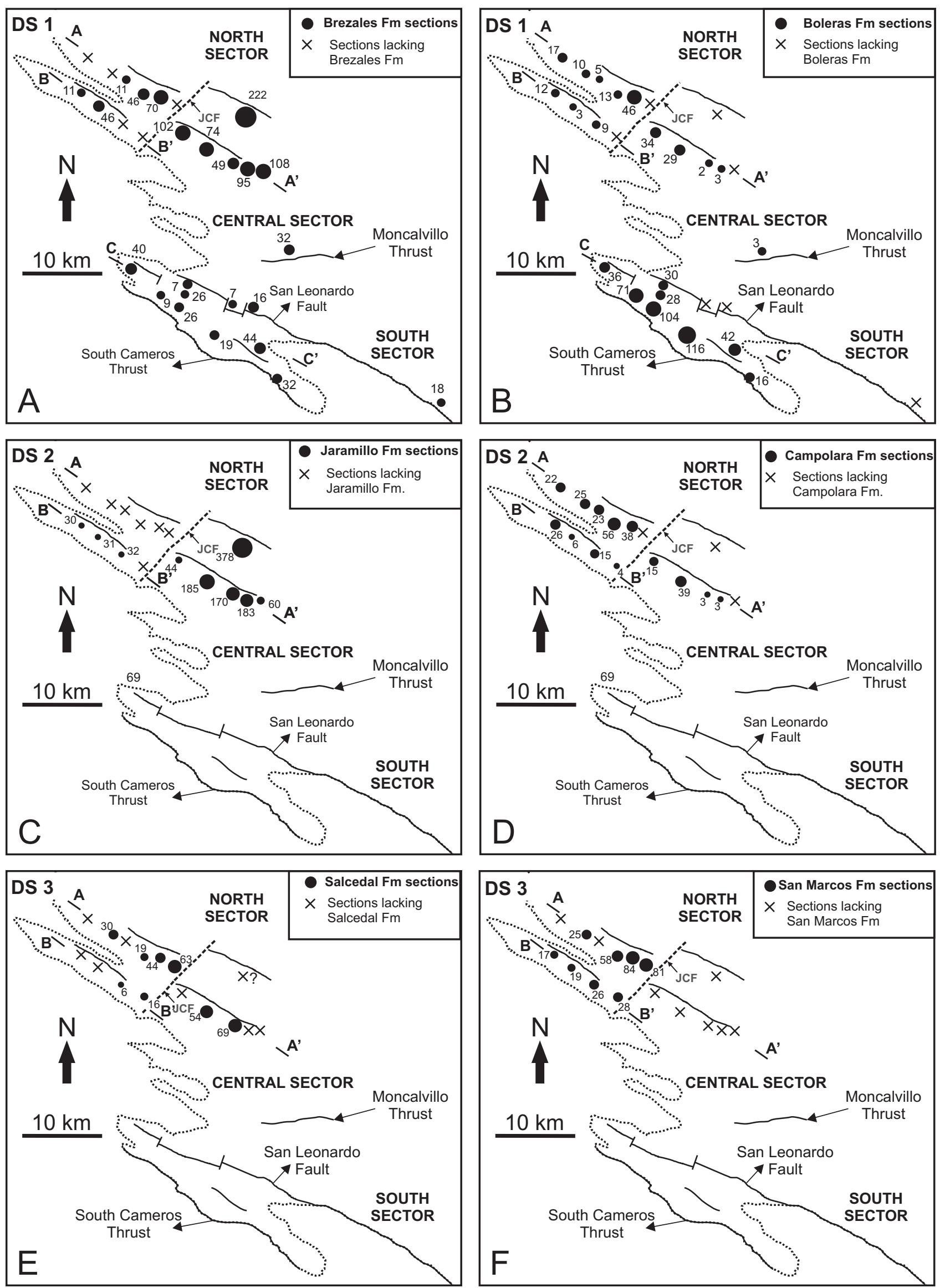

— Current thrusts

........... Current limit of the synrift sediments

JCF - Jaramillo-Covarrubias Fault 
NW

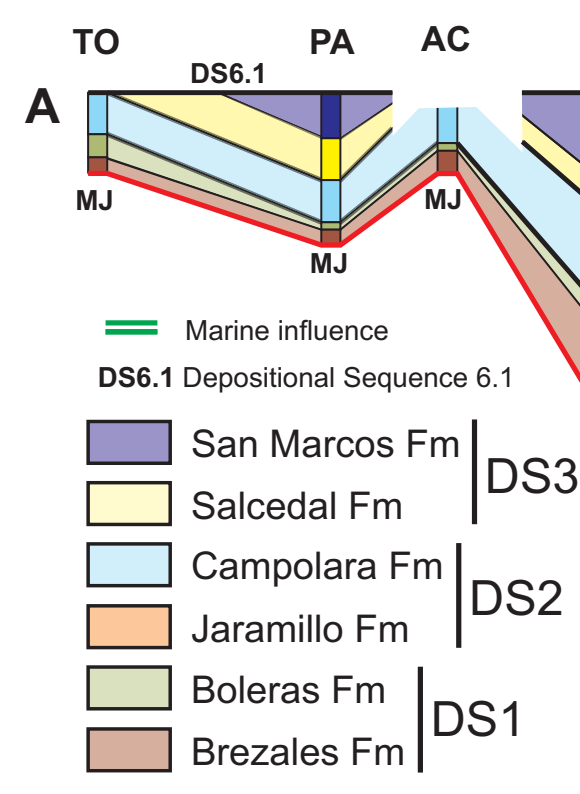

MJ: Marine middle Jurassic JQ MO $\underset{\text { DS6.1 }}{\mathrm{RU}} \mathrm{SM}$ PM PM CTV TR2 TR1 $=-1$

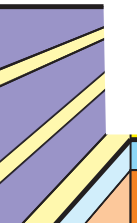
DS6.1 A'

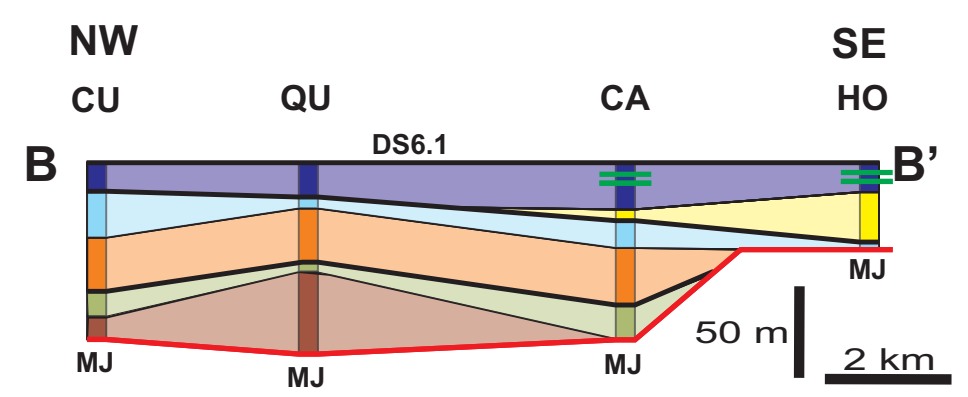

NW

DS5 


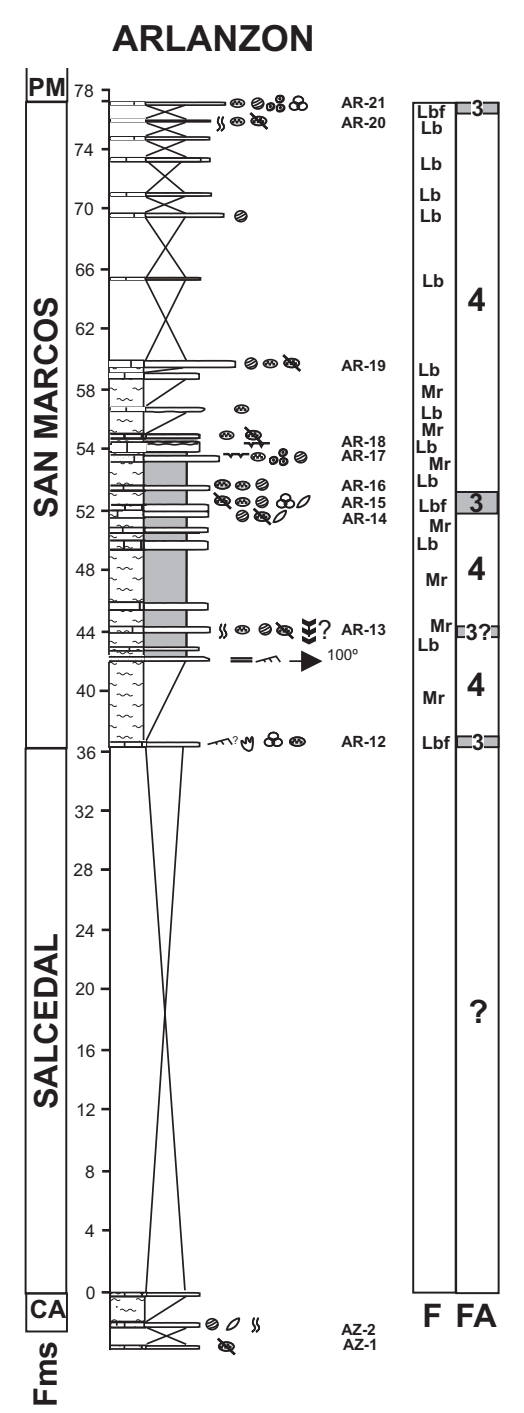

A -
PAULes

PM| ${ }_{48}$

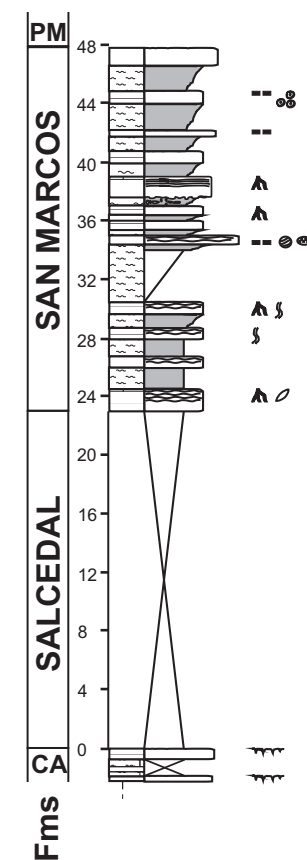

MORRION

PM

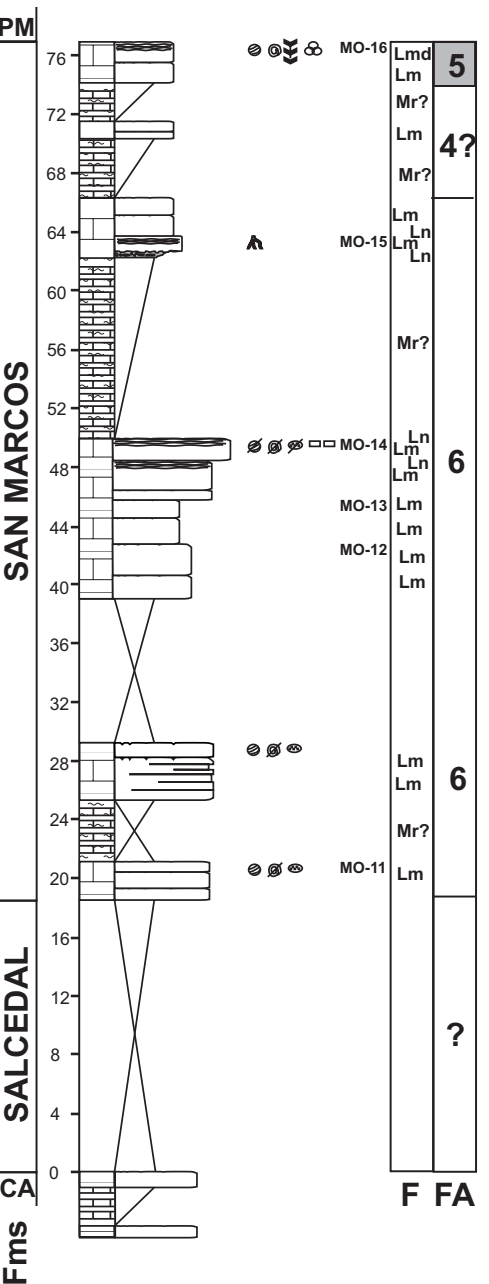

Fig. $2 \mathrm{C}$ and Fig. 4
RUPELO

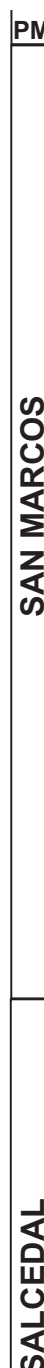

$\left.P M\right|_{124-}$

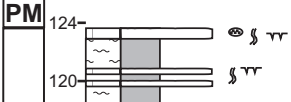

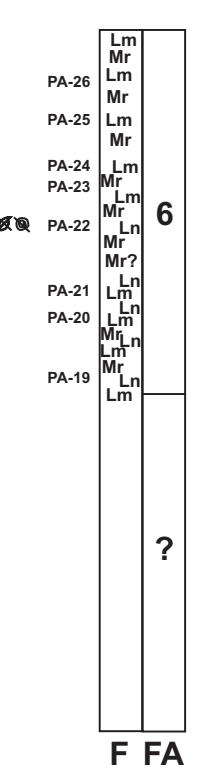

\section{LEGEND}

= Horizontal bedding

$\approx$ Planar cross-bedding

wँ Trough cross-bedding

NLateral accretion

त Ripple crosslamination

^ล Wave ripples

Flaser bedding

Vマ Desiccation cracks

Nodular bedding

(limestone)

rrr Pseudomicrokarst

A Root traces

(1) Carbonate nodules

$230^{\circ}$ Paleocurrent data
.

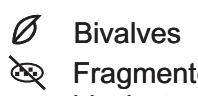

2. Fragmented

Dasycladales

므 Intraclasts

- Black pebbles

$\Downarrow$ Rivulariaceae

$8 \begin{aligned} & \text { Benthic } \\ & \text { foraminifera }\end{aligned}$

\$S Bioturbation

Fish scales and teeth

Y Dinosaur foot prints

๑ Oncoliths

Charophytes

(2) Ostracods

(a) Gastropods

massive calcrete

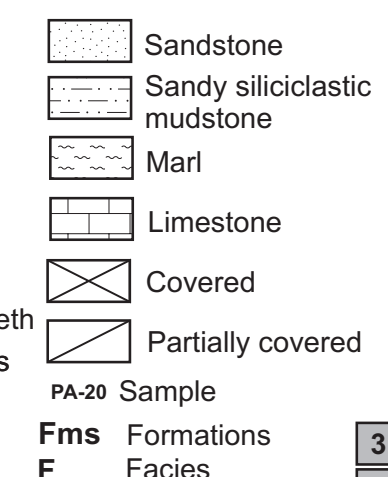

$\begin{array}{lll}\text { F Facies } & \text { influence } \\ \text { FA Facies Association } & \mathbf{5} & \text { episodes }\end{array}$
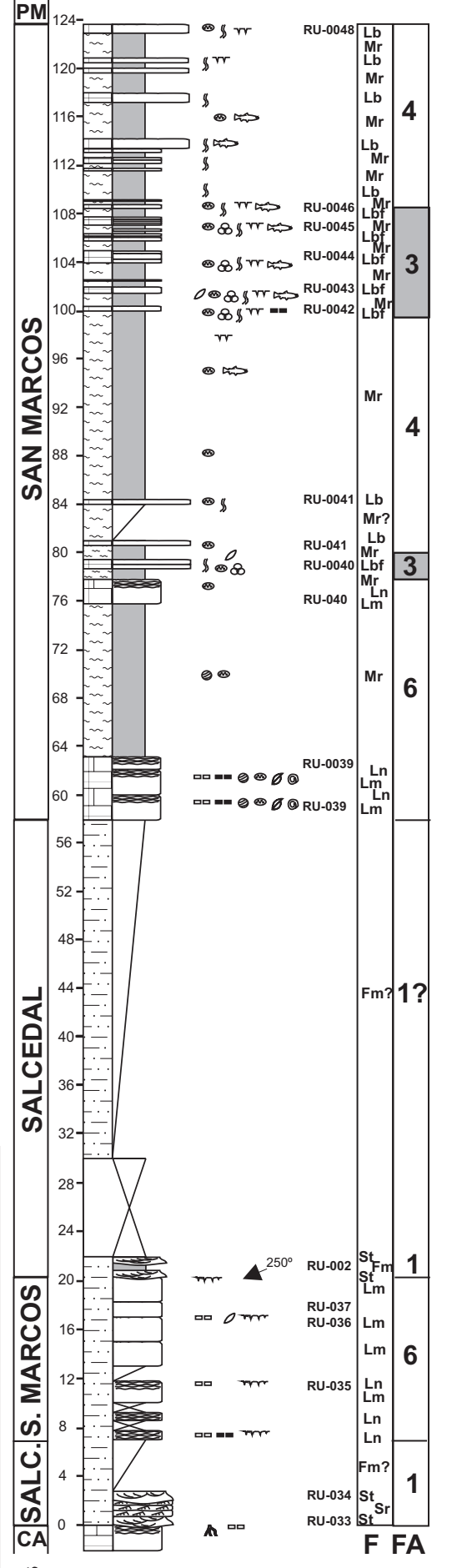

है

\section{CASTROVIDO}

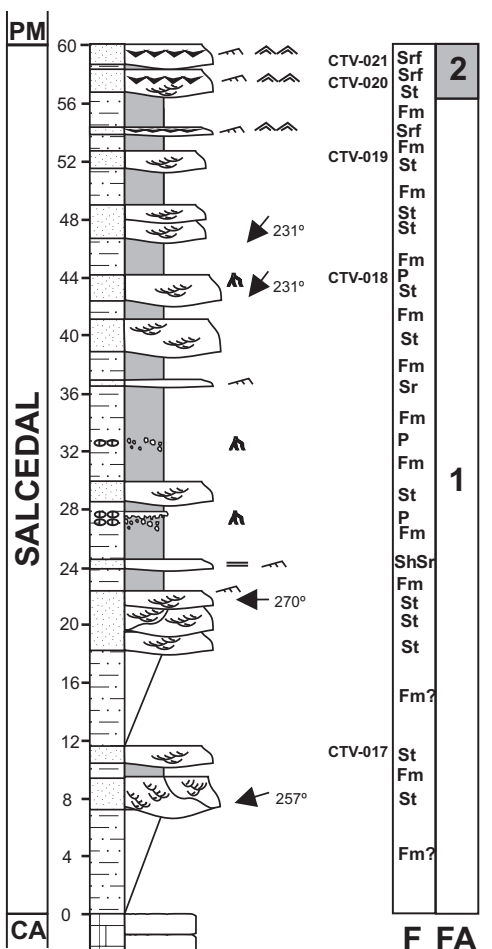

\section{B}

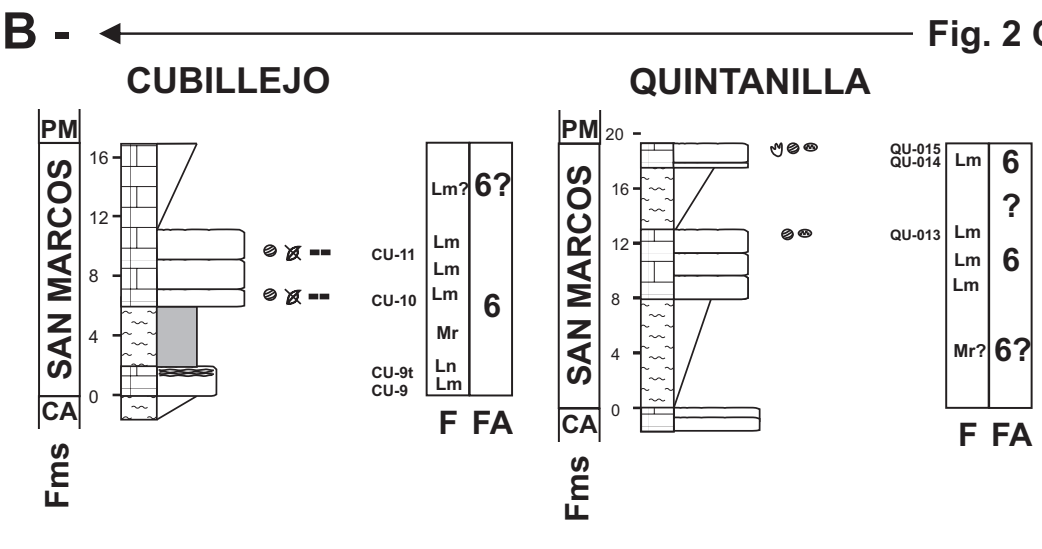

\begin{tabular}{l} 
PM = Pinilla de los Moros Fm (DS 6.1) \\
\hline Salcedal Fm + San Marcos Fm (DS 3) \\
\hline CA = Campolara Fm (DS 2)
\end{tabular}
Fig. $2 \mathrm{C}$ and Fig. 4

CAMPOLARA
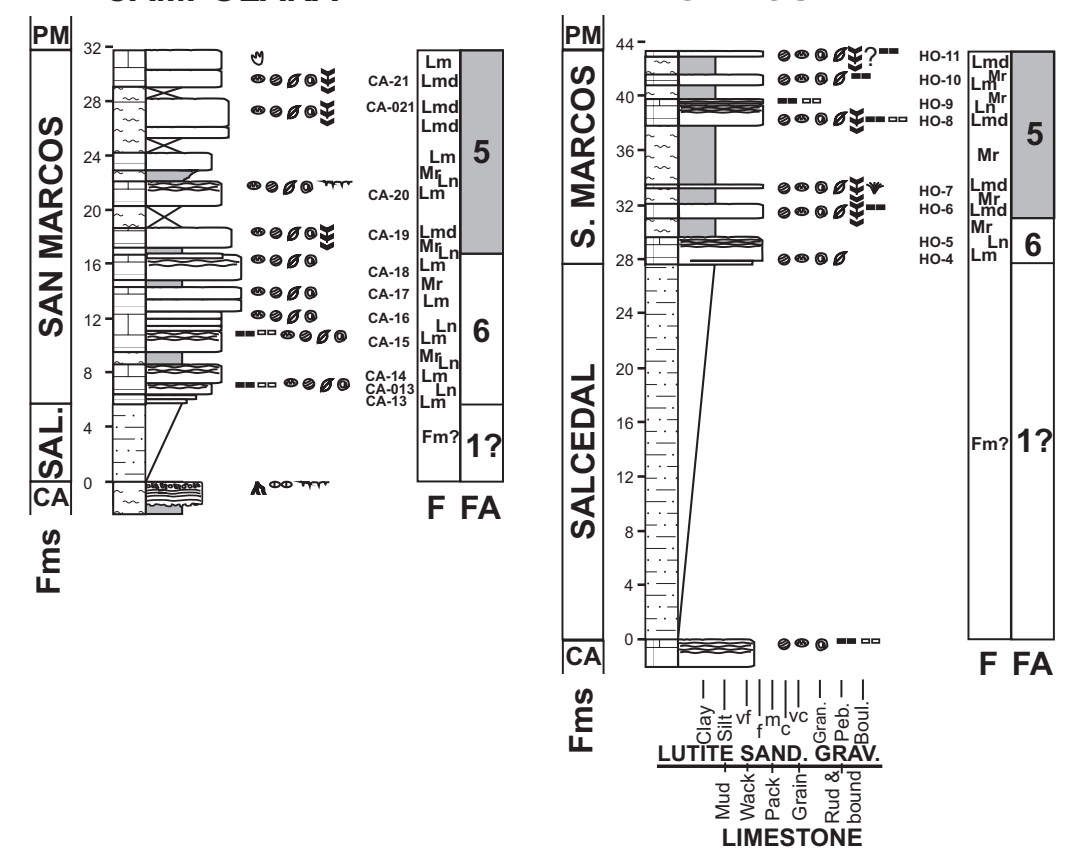


\section{ARCHITECTURAL ELEMENTS}

\section{FACIES ASSOCIATIONS}

SILICICLASTIC

\begin{tabular}{|c|c|c|}
\hline $\mathrm{CH}$ & (LA) & SB \\
\hline \multicolumn{3}{|c|}{$\begin{array}{l}\text { Floodplain fines extensive sheets up to several } m \text { thick } \\
\qquad \text { SB Sandy bedforms interbedded thin sheets (slightly erosive base) }\end{array}$} \\
\hline $\begin{array}{c}\text { Channels } \\
\text { CH } \begin{array}{l}\text { lens at least } \\
10 \text { 's } \mathrm{m} \text { wide }\end{array}\end{array}$ & $\begin{array}{l}\text { (LA) } \\
\text { Lateral-accretion } \\
\text { macroforms }\end{array}$ & SB Sandy bedforms \\
\hline
\end{tabular}

FA - 1

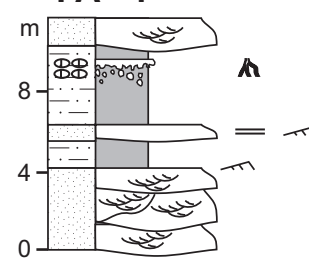

FA - 2

FACIES
St
P
Fm
Sh
Fm
St
St
St

FACIES

SMF Sandy to Mixed Flat extensive sheets and occasional chanels

MF Mud-flat fines extensive sheets up to few m's thick

SMF Sandy to Mixed Flat
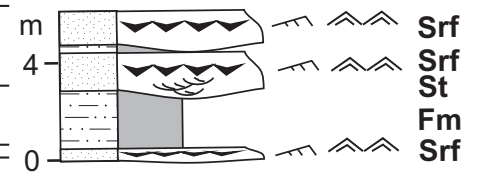

Interpretation

Meandering fluvial system

Siliciclasic tidal flat

CARBONATE AND MIXED CARBONATE - FINE SILICICLASTIC

\begin{tabular}{l|l|}
\multicolumn{2}{|c}{ Interpretation } \\
\hline $\begin{array}{l}\text { IMC } \\
\text { Interbedded Marl / Carbonate } \\
\text { tabular beds } \\
\text { extensive sets of cm's to m's } \\
\text { thick marl / carbonate rithms }\end{array}$ & $\begin{array}{l}\text { Limestone and marl deposited in } \\
\text { marine-influenced water bodies }\end{array}$ \\
\hline
\end{tabular}

FA - 3
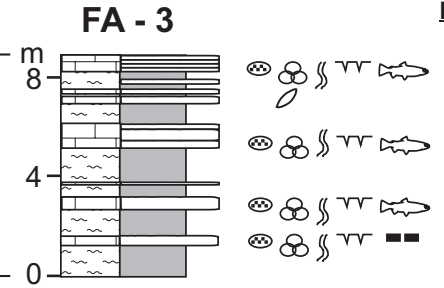

FACIES

Lbr

Mr

Mr

Lbf

$\mathrm{Mr}$

FA - 4

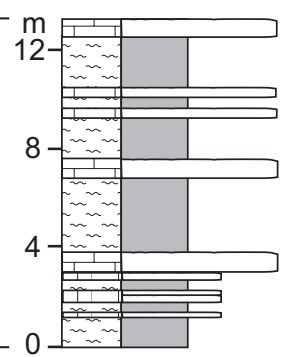

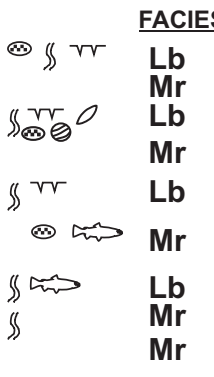

Interpretation

Carbonate coastal wetlands: quiet shallow marine-influenced water bodies with periodical subaerial exposure (desiccation).

\section{IMC}

Interbedded Marl / Carbonate tabular beds

extensive sets of cm's to m's thick marl / carbonate rithms
Limestone and marl deposited in water bodies with none or very little marine influence
FA - 5

\begin{tabular}{|l|l|}
\hline $\begin{array}{l}\text { CTB Carbonate tabular bodies } \\
\text { extensive bodies of carbonates }\end{array}$ & Palustrine limestone \\
\cline { 2 - 3 } $\begin{array}{l}\text { MTB Marl tabular beds } \\
\text { extensive bodies of marls }\end{array}$ & $\begin{array}{l}\text { Marl deposited in shallow } \\
\text { marine-influenced } \\
\text { water bodies }\end{array}$ \\
\hline CTB Carbonate tabular bodies & Lim. dep. in shallow marine-infl. w. b. \\
\hline MTB Marl tabular beds & Marldeposited in shallow marine-infl. w. b. \\
\hline CTB Carbonate tabular bodies & Limestone dep. in shallow marine-infl. w. b. \\
\hline MTB Marl tabular beds & Marl deposited in shallow marine-infl. w. b. \\
\hline
\end{tabular}

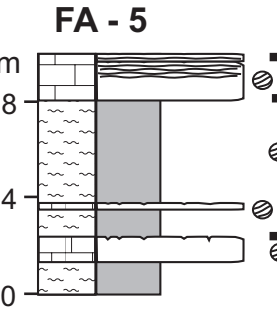

FA - 6

\begin{tabular}{|l|l|}
\hline $\begin{array}{l}\text { CTB Carbonate tabular bodies } \\
\text { extensive bodies of carbonates }\end{array}$ & Palustrine limestone \\
\cline { 2 - 2 } & Lim. dep. in sh. w. b. with n/v.l. marine infl. \\
\hline MTB Marl tabular beds extensive bodies & Dep. in sh. w. b. with n/v.l. mar. .infl \\
\hline \multirow{3}{*}{$\begin{array}{l}\text { CTB Carbonate tabular bodies } \\
\text { extensive bodies of carbonates }\end{array}$} & $\begin{array}{l}\text { Limestone dep. in shallow water bodies } \\
\text { with none or very little marine influence }\end{array}$ \\
\cline { 2 - 2 } & \begin{tabular}{l} 
Palustrine limestone \\
\cline { 2 - 2 }
\end{tabular} \\
\hline
\end{tabular}

FA - 6

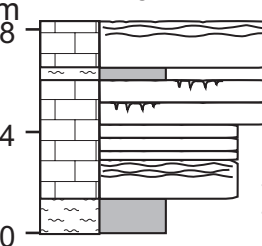

FACIES

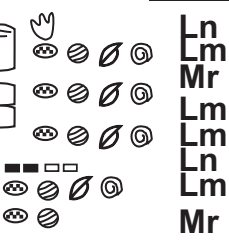

FACIES

Carbonate coastal wetlands: quiet shallow water bodies with none to very little marine influence. Periodical subaerial exposure (desiccation).

Addreviations: sh. $\mathrm{w} . \mathrm{b}$. = shallow water bodies; $\mathrm{n} / \mathrm{v} . \mathrm{l}$. = none or very little

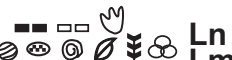
Mr quiet shallow marine-influenced Mr predominantly brackish water

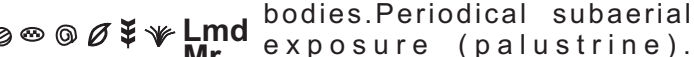

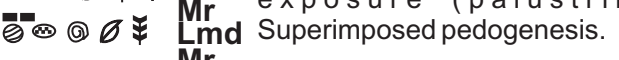
Mr

i



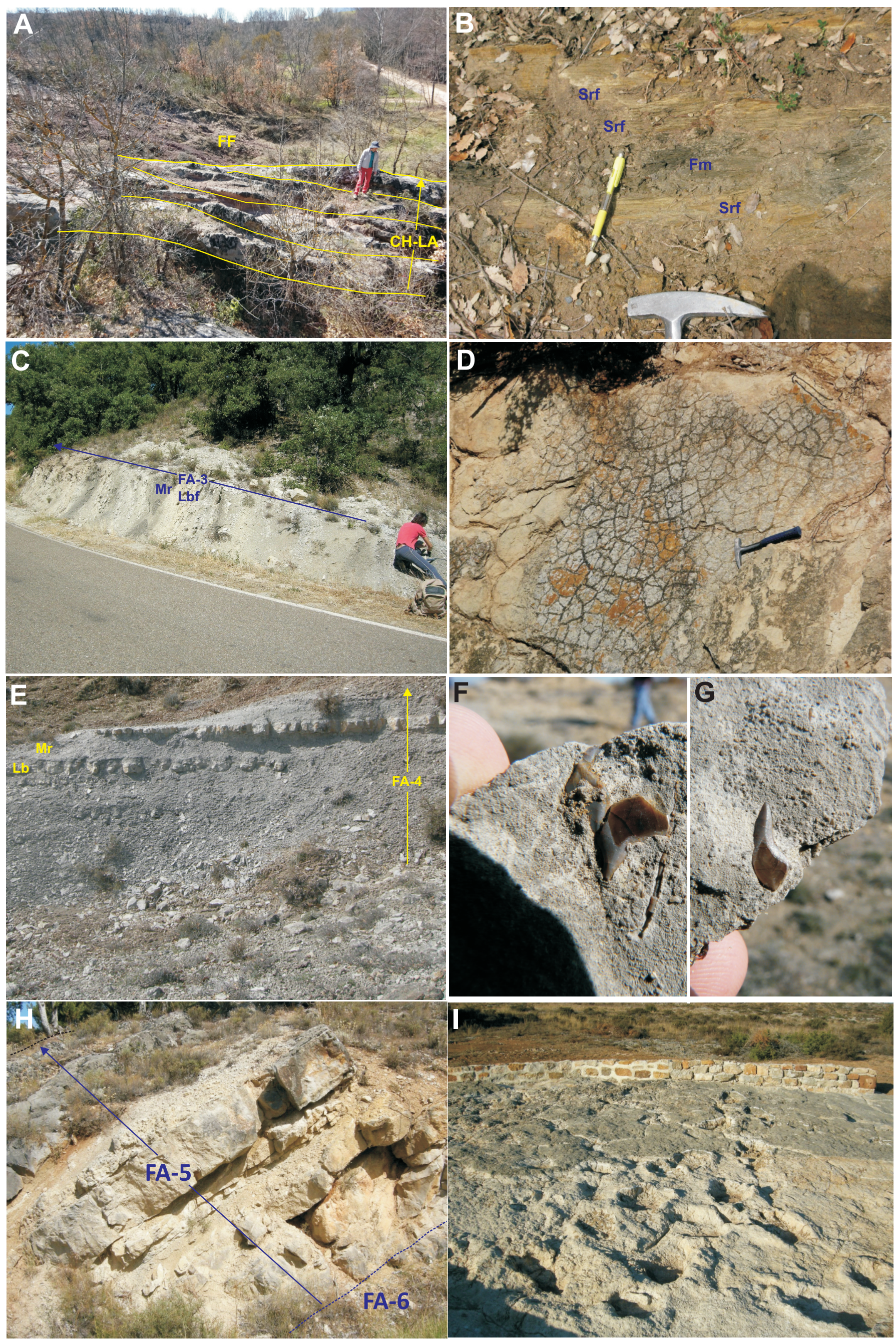


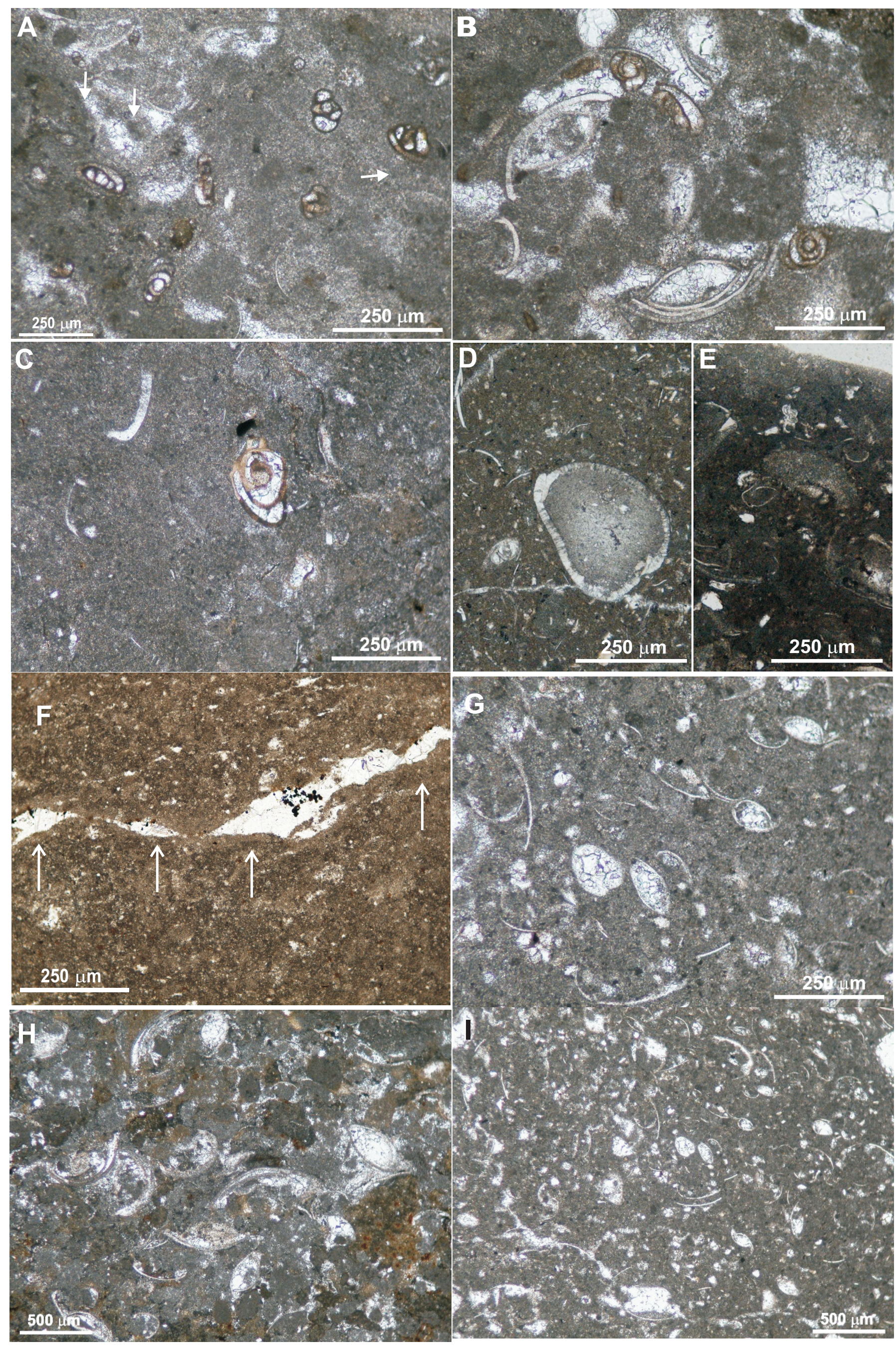

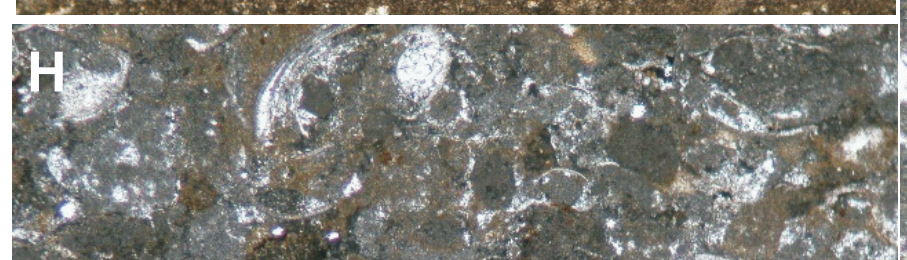

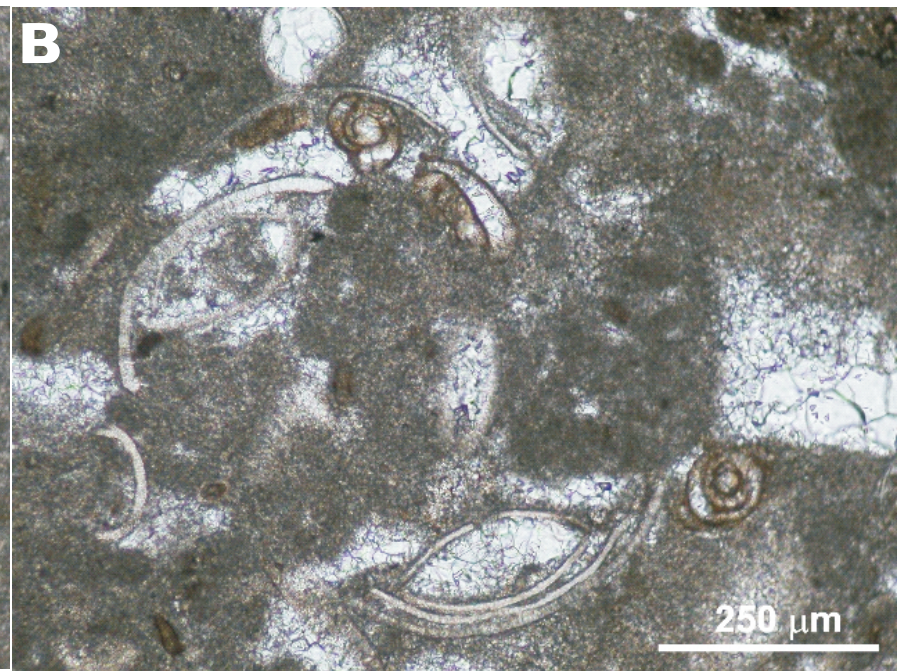




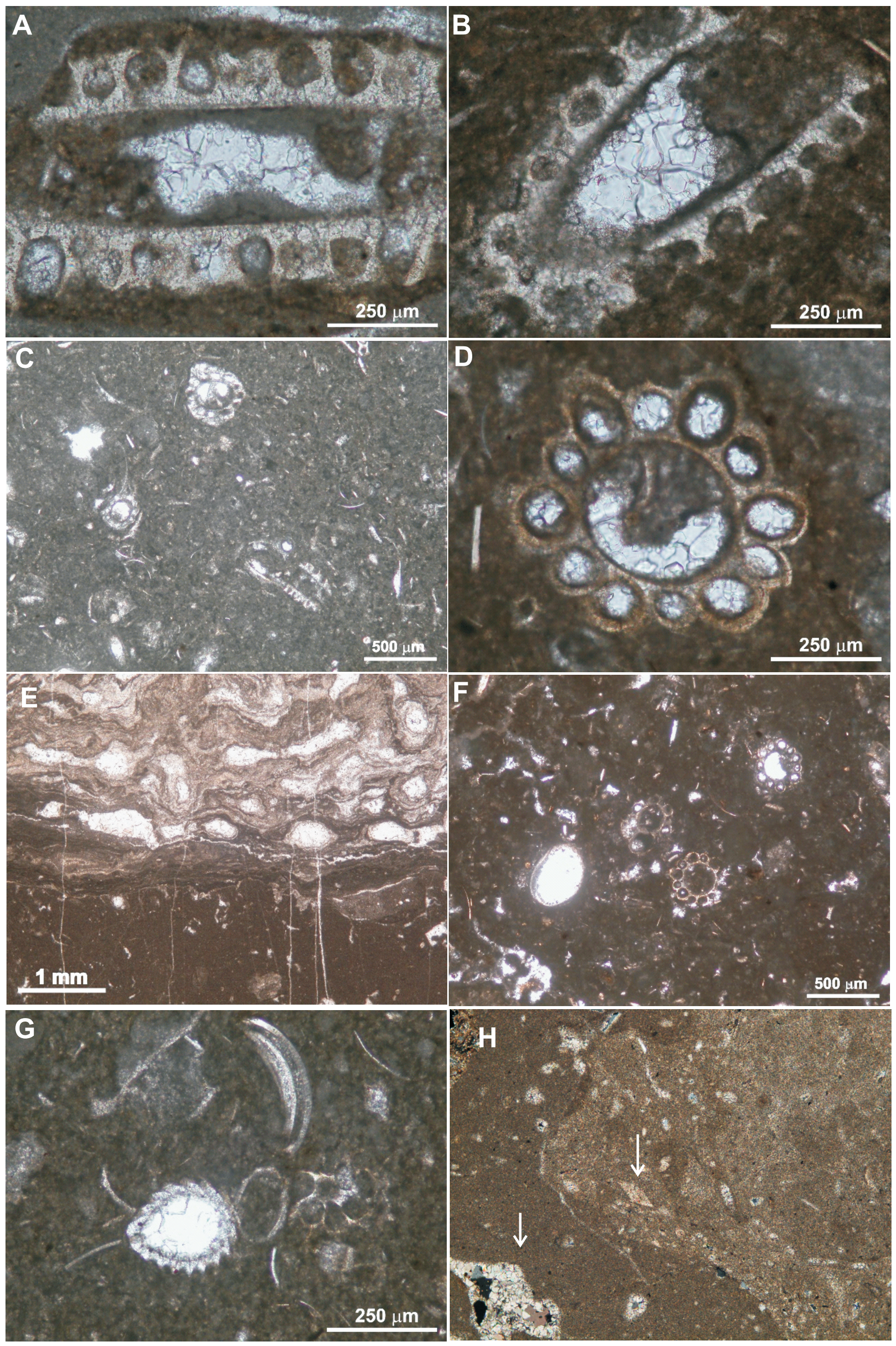



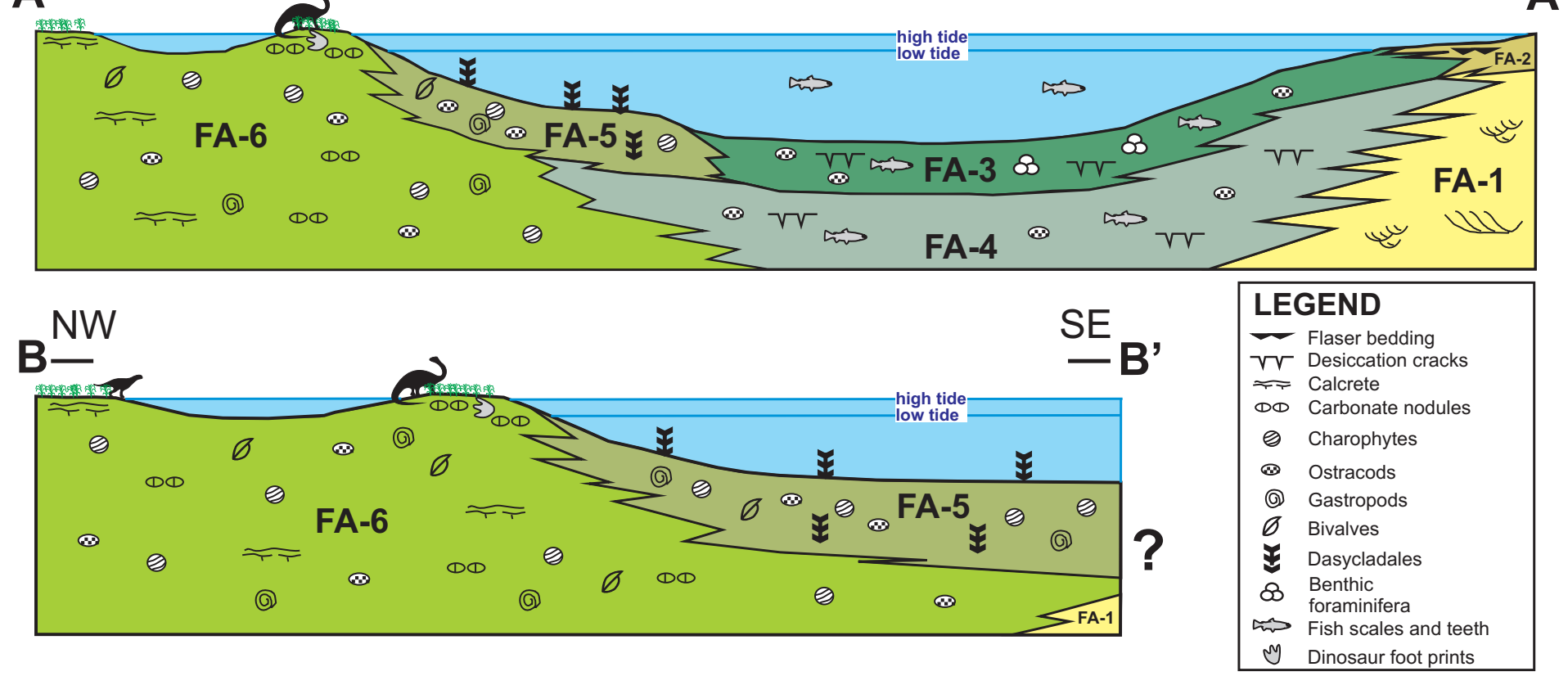

\begin{tabular}{|c|l|c|}
\hline $\begin{array}{c}\text { FACIES } \\
\begin{array}{c}\text { ASSOCIATIONS } \\
\text { (Figs. 6 and 7) }\end{array}\end{array}$ & \multicolumn{1}{|c|}{ DEPOSITIONAL ENVIRONMENTS } \\
\hline FA-1 & Fluvial meandering & \multirow{2}{*}{ Carbonate } \\
\cline { 1 - 2 } FA-2 & Siliciclastic tidal flat & \multirow{2}{*}{$\begin{array}{c}\text { Coastal } \\
\text { wetlands }\end{array}$} \\
\hline FA-3 & $\begin{array}{l}\text { Shallow carbonate water bodies with marine influence } \\
\text { and fine siliciclastic input }\end{array}$ \\
\hline FA-4 & $\begin{array}{l}\text { Shallow carbonate water bodies with none to very little marine } \\
\text { influence and fine siliciclastic input }\end{array}$ \\
\hline FA-5 & Shallow carbonate water bodies with marine influence \\
\hline FA-6 & $\begin{array}{l}\text { Shallow carbonate water bodies with none to very little marine } \\
\text { influence and palustrine areas }\end{array}$ &
\end{tabular}




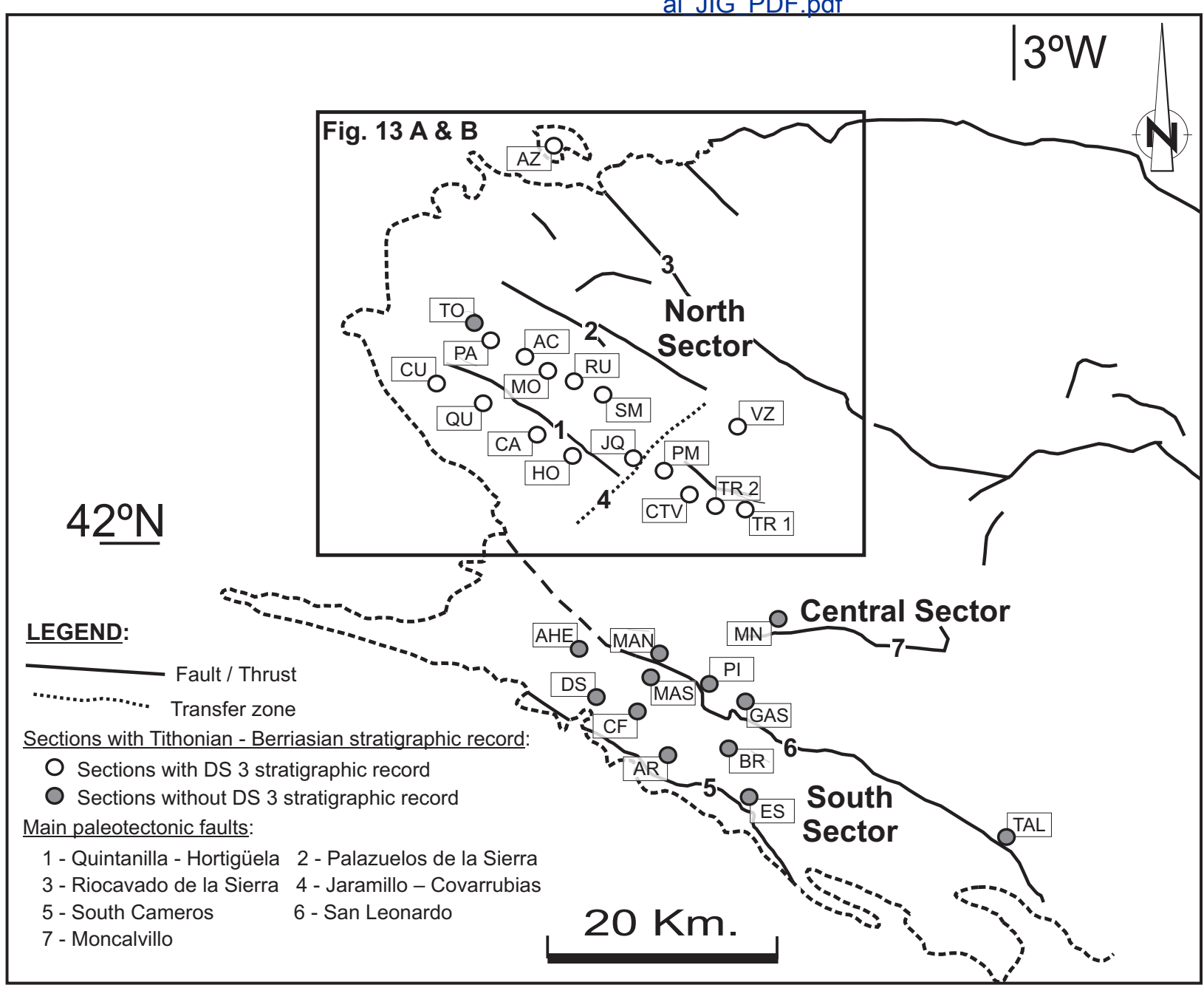




\section{Eigpare}

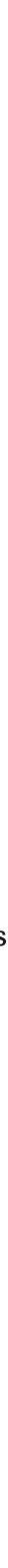

Click here to access/download;Figure;Fig_14_Mas-et-

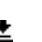




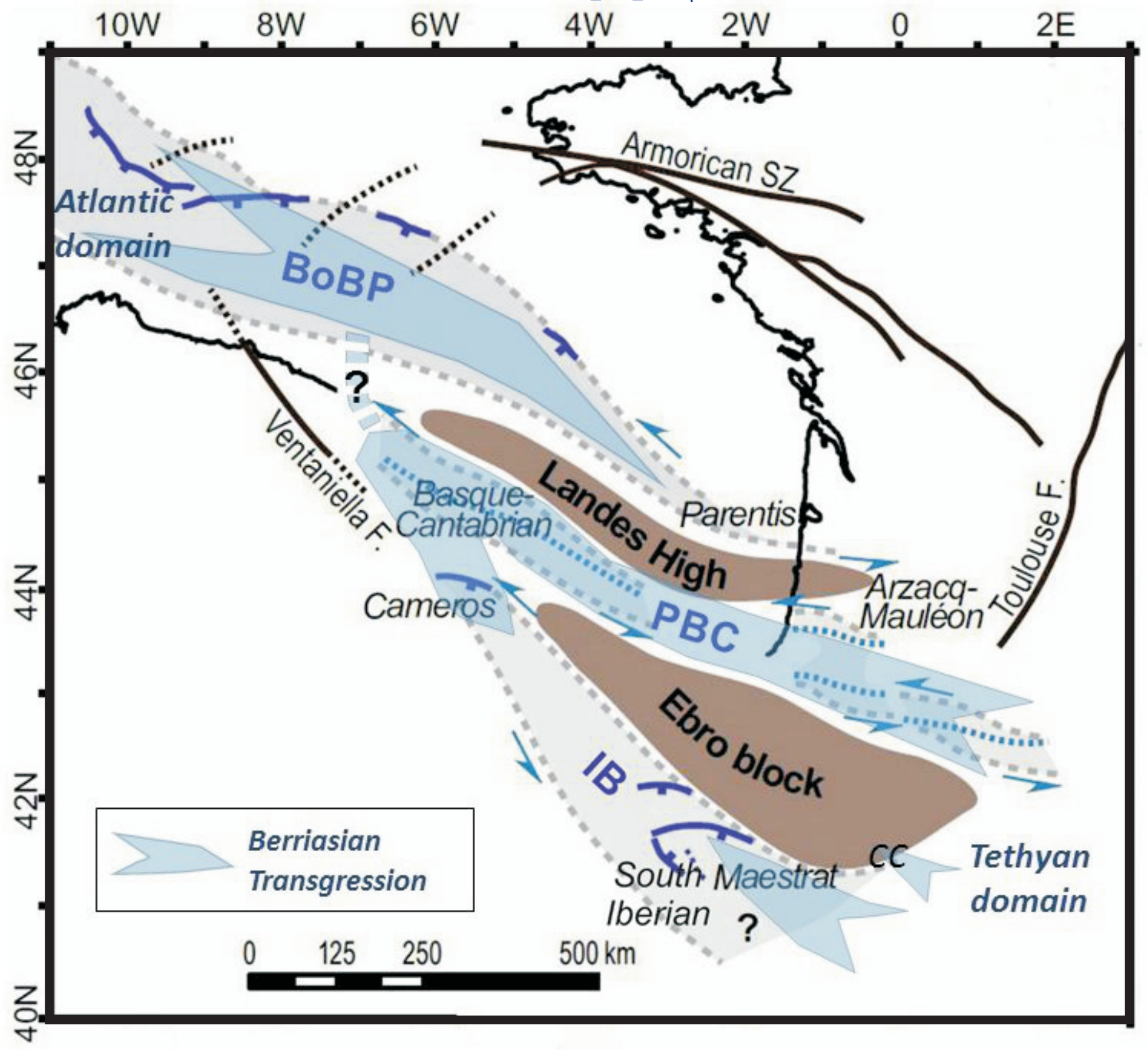

